\title{
LEADERSHIP PROCESS MODELS: A REVIEW AND SYNTHESIS
}

\author{
Thomas Fischer \\ University of Lausanne \\ Joerg Dietz \\ University of Lausanne \\ John Antonakis \\ University of Lausanne
}

Reference:

Fischer, T., Dietz, J., \& Antonakis, J. (2017). Leadership process models: A review and Synthesis. Journal of Management, 43(6), 1726-1753.

Corresponding author: Thomas Fischer, Department of Organizational Behavior, Faculty of Business and Economics, University of Lausanne, Internef 621, CH-1015 Lausanne-Dorigny, Switzerland.

Email: thomas.fischer@unil.ch

Supplemental material for this article is available at http://xxx.sagepub.com/supplemental. 


\begin{abstract}
In organizational research, studying "processes" is important for uncovering and understanding the underlying causal mechanisms in a predictor-mediator-outcome logic. Processes answer "how" and "why" questions and provide more complete explanations about phenomena. Our focus in this review is on studies of leadership processes, which we systematically analyze to report on the state-of-the science. In doing so, we present a two-dimensional target-centric taxonomy to integrate previous research: The taxonomy distinguishes the target's level (i.e., individual follower, team, organizational, and extra-organizational) as well as the type of leadership processes that affect either the target's development or leverage of resources. Our review indicates that the predominantly studied leadership "meta" process model looks at the effect of leader traits or behaviors on performance-related outcomes through cognitive, affective, or behavioral leveraging factors. This "meta" model points to several important and understudied processes including a leader's influence on the target's development or work context. We also identify two largely overlooked yet critical issues for leadership process research: Modeling the role of time and that of multiple processes through which leadership effects manifest themselves in organizations. Using our taxonomy, we provide several reflection points that can guide the development of genuine and thoughtful leadership process theories. We conclude by urging future leadership process research to embrace multi-process, multi-level, and time-sensitive models.
\end{abstract}

Keywords: Leadership, process model, mediation, theorizing, time, taxonomy, causality. 
Leadership is a social and goal-oriented influence process, unfolding in a temporal and spatial milieu. In this process, leadership variables, such as a leader's behaviors, affect a distal outcome like team performance through more proximate mediating constructs such as follower motivation (Antonakis, Day \& Schyns, 2012); the term "leadership" implies that a leader has a greater impact on a single follower than vice versa. Identifying such processes is challenging because the effects on mediating constructs or on outcomes do not necessarily occur within the same temporal and spatial dimensions (cf. Senge, 2014). Yet, such process knowledge is crucial for two reasons. Process models inform about the "how" and "why" of effects and thereby allow assessing generalizability and boundary conditions (Dubin, 1976). Moreover, such knowledge helps practitioners to make the right choices: Whether, for example, a values- or incentivesbased leadership approach is more effective in raising performance depends on the mechanisms behind these approaches (e.g., identification versus reward contingencies) in the specific context, and the time it takes for these effects to unfold.

We organize and clarify leadership processes to identify challenges and opportunities for future research. We use the term "process" to refer to the mechanism that explains the causal relationship between inputs (e.g., leader behaviors) and outputs (e.g., performance), following an input-process-output logic (see Hutzschenreuter \& Kleindienst, 2006; Van de Ven, 1992 on strategy process research); that is, "process" refers to a cause-mediator-effect logic. Thus, we synthesize and assess research linking leadership with performance and performance-related outcomes (e.g., turnover due to hiring and training costs as well as productivity losses) via its mediating mechanisms; of course, as will be evident later, finding mediation does not guarantee that a process is being studied. 
Our review focuses on articles published since 1990 given that research on leadership processes began in earnest only after Baron and Kenny's (1986) work on mediation (see online Appendix 1). We provide guidance and theoretical undergirding for developing causally rigorous, process-oriented leadership models. We complement related reviews that have studied leadership theories per se, levels of analysis, outcomes (but not mediators of leadership), or the organization of leadership along its loci and influence mechanisms (e.g., see DeChurch, Hiller, Murase, Doty \& Salas, 2010; Dinh, Lord, Gardner, Meuser, Liden \& Hu, 2014; Hernandez, Eberly, Avolio \& Johnson, 2011; Hiller, DeChurch, Murase \& Doty, 2011). Such work provides an understanding of how different leadership theories are supposed to operate. With our review, we add insights on how leadership effects unfold via mediating mechanisms across levels and time. In this way, we address van Knippenberg and Sitkin's (2013) concern about the scarcity of mediational explanations in leadership theories; and, we heed the call of Davis and Marquis (2005) for mechanism-based explanations of organizational phenomena.

Our review makes three key contributions. First, we present a two-way taxonomy along levels of analysis and types of leadership processes; the latter refers to whether a leader influences performance through developing resources or leveraging them. The taxonomy provides a basis for illustrating the mechanisms through which leadership unfolds and for pinpointing foci and gaps of past research. Second, our review provides a foundation for process theorizing by elaborating on two key aspects: (a) the explicit treatment of time in leadership research and (b) the need to consider multiple leadership processes simultaneously. Leadership research has given temporality short shrift, although understanding how leadership unfolds over time is integral for theoretical precision and practical relevance. Hence, we put forward taxonomy-based recommendations for modeling temporality in process models. Additionally, we 
discuss that mono-mediator reasoning can easily result in discovering "specious mediators," mediators that appear to channel an effect but do in fact not do so. Third, using our taxonomy, we suggest reflection points to guide theorizing and testing of sufficiently robust yet practically executable models. We illustrate the usefulness of these reflection points with an example from empowering leadership.

The remainder of our review has four sections. First, to organize the reviewed research, we introduce a taxonomy of mediation constructs of leadership. Second, we review how previous research has modeled time and make suggestions for taking the dynamic nature of leadership into account. Third, we address the risk of "specious mediators" and the need to model multiple leadership processes. Fourth, we offer reflection points to guide developing and testing leadership process theories and conclude with recommendations for future leadership process research.

\section{REVIEW AND INTEGRATION OF LEADERSHIP PROCESS RESEARCH}

\section{Systematic Review and Coding}

To identify the articles to be reviewed, we selected journals that-among the 50 journals in our field having the highest 5-year impact factors—-publish work on leadership (see online Appendix 2); these journals have mean and median two-year impact factors of 3.08 and 3.04 and five-year impact factors of 4.97 and 4.33 respectively. Then, we searched in Web of Science articles that were published between 1990 and 2015 in these journals. The search terms were either "leader*," “manager," “executive”, “CEO”, “top management team”, or “TMT” plus "mediat*" plus "performance" or "effectiveness." The search yielded 657 articles.

To arrive at a representative sample, we randomly drew a subset of articles (i.e., $n=350$ ), as previous researchers have done too (Antonakis, Bendahan, Jacquart \& Lalive, 2010; Bergh \& 
Perry, 2006). We excluded articles that did not cover leadership, did not propose or test a mediation model, studied outcomes that were unrelated to performance (e.g., CEO compensation), or were retracted. The final sample consisted of 205 articles, which the first author coded. Of these articles, around 92\% were quantitative empirical, $3 \%$ theoretical, $2.5 \%$ reviews, $2 \%$ meta-analyses, and $0.5 \%$ qualitative empirical articles. To ensure reliable coding, a Ph.D. student in organizational behavior independently coded a sample of 20 articles having 136 coding events. Expected agreement of the two coders, due to chance was $29.87 \%$; the coders agreed on $78.68 \%$ of events. The agreement statistic, $\kappa=.70, \mathrm{SE}=.05, z=15.30, p<.001$, showed that agreement was better than chance and "substantial" (Landis \& Koch, 1977). Disagreements were then resolved and the coders agreed in $100 \%$ of the cases.

\section{The Taxonomy of Leadership Mediation Constructs}

In coding the articles, it became evident that research on leadership process models can be organized along two dimensions: (a) the influenced entity's level of analysis and (b) the type of leadership process (see Table 1 for exemplary mediating constructs and articles; also see Figure 1 for a graphic illustration).

[Insert Table 1 and Figure 1 about here]

In terms of level of analysis, we distinguish entities at the individual, team, organization, or extra-organizational level. Throughout the manuscript, we refer to these entities as targets. The targets or their attributes such as their skills or motivation in the case of individuals, supposedly change due to leadership influences. The rationale for the target-centric dimension level of analysis lies in the multi-level effects of leadership (Yammarino, Dionne, Chun \& Dansereau, 2005). For example, although interpersonally skilled leaders might be effective at the individual level, their performance might suffer from an inability to form high-performing teams 
(Hogan \& Kaiser, 2005); leaders might even become destructive if they steered their followers in a direction opposed to the legitimate interests of the organization (Krasikova, Green \& LeBreton, 2013). In the coded articles, the vast majority of mediators referred to targets, indicating a prevalence of leadership mediation models that combine leader-related predictors with targetrelated mediators (see Uhl-Bien, Riggio, Lowe \& Carsten, 2014).

For the dimension type of leadership process, we identify if leaders affect performance through developing resources or leveraging them. For example, at the team level, a leader can (a) support learning processes and thereby affect the development or exploration of new skills, or (b) increase team efficacy and thereby affect leverage or exploitation of skills. Similarly, leaders can shape development and leverage of organizational resources, or they can manage the external relations and provide access to resources for their organization (e.g., through networking). We use the term "development" as the set of resource-enlarging concepts ranging from individualand/or team-level mentoring (Higgins \& Kram, 2001) and coaching (Hackman \& Wageman, 2005) to team (Day, Gronn \& Salas, 2004) and organizational-level learning (Vera \& Crossan, 2004). "Leveraging" refers to the impact on constructs like efficacy that facilitate the use of resources, such as the expertise of followers or the information to which a team has access.

The rationale for the dimension "type of leadership process" is derived from an application of the ability-motivation-opportunity (A-M-O) framework for individual job performance (Blumberg \& Pringle, 1982). Development refers to increasing an entity's resources, such as its ability; leverage is a generalized concept of an individual's motivation to perform or the willingness to better exploit resources. Moreover, access to resources from a higher level (see the diagonally upward pointing arrows in Figure 1) is conceptually similar to the notion of opportunities in the A-M-O framework. For instance, access to budgets provided by 
the organization can raise the performance of a team. Examples of securing access to extraorganizational resources are leading regional and industry clusters (Sydow, Lerch, Huxham \& Hibbert, 2011) as well as boundary spanning and tightening activities (Somech \& Khalaili, 2014). Together, developing resources, leveraging them, and acquiring resources from higher levels determine the performance of an entity.

The A-M-O framework reveals parallels of leadership to other sub-fields of management, such as strategic human resource management (strategic HRM; Wright \& Snell, 1991). Strategic HRM shares with leadership a key concern: Which kind of inputs (e.g., human resources or followers) do organizations need and how do organizations develop and leverage the inputs for desired outcomes (e.g., job performance)? In strategic HRM, staff is developed via training; appraisals and compensation practices serve to leverage the potential of the staff, and recruitment from the labor market creates opportunities for raising the quality of the staff. Leadership and strategic HRM are both goal-directed influence processes, just with different inputs and foci in varying contexts.

\section{Results of the Systematic Review}

Having explained the selection and coding of articles and our categorization method, we report the results of our review. Figure 2 provides an overview of the most commonly studied predictors, mediators, and outcomes. The most frequently used predictors are leader-related (e.g., leader behaviors), ahead of follower-related variables (e.g., follower demographics), dyadic variables (e.g., LMX), and contextual factors (e.g., environmental uncertainty) (see online Appendix 3). Among mediators, target-centric constructs dominate (e.g., followers' justice perceptions). The three most often studied predictors point to a prevalence of theories of transformational leadership, LMX, and traits in mediation models. Dinh et al. (2014, see their 
Table 3) had also identified these predictors as being among the most heavily examined leadership constructs. Similarly, in an analysis of middle-range leadership theories (Meuser, Gardner, Dinh, Hu, Liden \& Lord, 2016), transformational and trait approaches emerged as focal theories.

\section{[Insert Figure 2 about here]}

Leadership mediation research focuses mostly on the individual level, followed by the team level and, to a lesser extent, the organizational and extra-organizational levels. Most research at the individual level and the team level addresses leveraging processes, which we can parse out into cognitive, affective, mixed cognitive-affective, and behavioral constructs. Nearly half of the individual-level leveraging mediators are cognitive constructs (see online Appendix 4). Additionally, Table 2 reports frequencies on methodological issues in leadership mediation research, such as accounting for multiple mediation paths, avoiding same-source variance, using exogenous and instrumental variables, and including time lags (see also online Appendix 5 for coded trends over time).

\section{[Insert Table 2 about here]}

In summarizing these results, we make three key observations. These observations concern the dominance of target-centric leverage mediating constructs, the chasm of organizational research into a micro-behavior versus a macro-strategic leadership orientation, and various methodological shortcomings. First, whereas much research examines leverage mediators, studies of leadership influences via developmental mediators (Day \& Dragoni, 2015) or job enrichment variables (Oldham, Hackman, Smith \& Hitt, 2005) are rare (see Figure 3). We speculate that a fascination with the direct influences of leaders on followers relative to indirect influences by, for example, designing work flows, partially explains the uneven distribution of 
mediating constructs. Another reason might be the ease with which data on follower-related mediators can be obtained, for example, through questionnaire measures. Future research should benefit from attending to job characteristics, objectively defined, as mediating constructs (e.g., see Piccolo \& Colquitt, 2006, though their measures were subjective).

[Insert Figure 3 about here]

Second, our results point to two major research camps: (a) organizational behavior-type research at mostly the individual and team levels and (b) upper echelon and strategic leadership research at mostly the team and organization levels. Whereas organizational behavior-type research typically examines influences on leveraging resources, upper echelon research normally links CEO or top management team characteristics (i.e., inputs) to strategic decisions and corporate performance (Finkelstein, Hambrick \& Cannella, 2009). The two camps can crossfertilize each other, for example, in studying TMT processes (Carmeli, Schaubroeck \& Tishler, 2011) or influences of leaders on organizational effectiveness (Yukl, 2008).

Third, our review reveals that numerous theoretical and methodological concerns undermine the ability of research on leadership processes to inform policy. Many mediation models are neither fully and robustly tested nor correctly specified to ensure correct identification of causal effects. Furthermore, most mediation models ignore the temporal dimension of leadership, an issue, to which we attend specifically next. In particular, following a review of the treatment of time in past leadership research, we discuss why modeling time is important and give recommendations for how to include time in leadership process models.

\section{IT IS TIME TO PUT TIME INTO THEORIZING AND TESTING}

Process research has to take the role of time serious (Langley, Smallman, Tsoukas \& Van de Ven, 2013). In the same way, leadership process research needs to study how effects unfold 
over time. Yet, despite several pleas over the decades (Day, 2014; Day \& Lord, 1988; Shamir, 2011), conceptual and empirical work in leadership has neglected the role of time. Addressing this gap, we (a) reveal implicit assumptions about time in leadership research, (b) discuss different temporal configurations of leadership, (c) elaborate on unfolding time (i.e., how long it takes for effects to materialize) and persistence of leadership effects, and (d) caution against using non-theory-based time lags. In doing so, we complement recent methodological efforts to find optimal time lags (Dormann \& Griffin, 2015) with conceptual considerations to examine leadership processes.

\section{Implicit Temporal Assumptions}

As indicated in Table 2, predominant designs in leadership research include experiments in which the mediator and outcome are measured relatively soon after the manipulation, as well as cross-sectional and pseudo-longitudinal studies that measure all constructs simultaneously or measure the cause before mediators and outcomes, respectively. Moreover, most studies rely on questionnaire measures, which can distort inferences about time. Such designs make implicit temporal assumptions regarding the immediacy of effects and/or a stable equilibrium among these effects. Given a research context in which such assumptions are met, no specific modeling of time is required. Otherwise, as we discuss below, careful attention needs to be paid to the role of time both in designs and measures.

Experimental designs, particularly in the laboratory, commonly assume the immediacy of effects, in which a predictor $x$ is a temporally proximal cause of mediator $m$, which in turn immediately affects an outcome $y$. For example, a manipulated leader behavior $(x)$ immediately causes a perception (e.g., $m$ ), which promptly affects an outcome (y). Burris (2012) built on these assumptions, when he manipulated voice and subsequently measured the mediators perceived 
loyalty and threat as well as the criteria performance ratings and endorsement of ideas. If, however, effects do not materialize instantaneously, immediate subsequent measurement leads to an underestimation of results.

Cross-sectional research, which, by definition, cannot model temporal order, assumes a stable equilibrium of effects. That is, a cross-sectional design is only appropriate when the predictor $x$, the mediator $m$, and the outcome $y$ are stable and the relationships among them do not fluctuate over time. Stated differently, $x$ must be constant across time and must consistently have the same impact on $m$, which must have a constant effect on $y$. Studies of the effects of stable leader traits on managerial performance via the mediating process transformational leader behavior (e.g., Cavazotte, Moreno \& Hickmann, 2012) probably meet this assumption.

Despite the abovementioned examples in which the assumption of immediacy or that of a stable equilibrium of effects hold, we judge it likely that many studies violate these assumptions and, thus, produce, flawed findings. Moreover, questionnaire measures of leadership can undermine inferences about time for three reasons. First, such measures are retrospective accounts, which are prone to distortion from peak-end effects and duration neglect (Fredrickson \& Kahneman, 1993), hindsight bias, social desirability (Golden, 1992), and performance cueeffects (Lord, Binning, Rush \& Thomas, 1978). Day (2014) argued that questionnaires might even capture raters' expectations of future leader behavior. Second, questionnaire measures rarely specify the period of time for which a leadership behavior is assessed, thereby rendering the temporality of relations non-interpretable. Third, leadership questionnaires typically take a "person-whole" perspective that captures general or aggregate tendencies of a leader. This perspective ignores that behaviors can be geographically and temporally rooted, thus possibly misrepresenting what leaders do in situ (Hoffman \& Lord, 2013). In sum, retrospectivity, 
unspecified time frames, and person-whole approaches severely limit inferences about temporality and thereby causality (Hunter, Bedell-Avers \& Mumford, 2007).

An event-based "person-parts" approach could partially address these limitations. Events can be seen as episodes where actions intersect with a context (Rousseau \& Fried, 2001). Seen through an event-based perspective, repeated leadership behaviors are events; and repeated sampling of these events allows tracing within-individual differences over time. Moreover, as events, leadership behaviors have effects that unfold in space and time and cause new events (e.g., behaviors of targets) (Morgeson, Mitchell \& Liu, 2015). That is, leadership behaviors enacted at one point in time in one location, and not broad behavioral tendencies of leaders, affect temporally and locally situated follower attributes, such as their attitudes; it is these attitudes in turn, which have an impact on performance.

\section{Alternative Temporal Configurations of Leadership}

Event-based thinking invites reflection about temporal configurations above and beyond immediacy and stability of effects. Drawing on Mitchell and James (2001), we apply four such configurations, which can serve as a foundation for a theory-based treatment of time in leadership process research (Ancona, Goodman, Lawrence \& Tushman, 2001; Shipp \& Cole, 2015). For simplicity, we use basic $x \rightarrow m$ relations, but an extension to $x \rightarrow m \rightarrow y$ relations (i.e., complete mediation models) is easily feasible.

Unstable predictor-outcome relationship. With a continuous treatment (i.e., ongoing events), a predictor $x$ affects an outcome $m$, but the effect of $x$ on $m$ changes over time. For example, the effect of charisma on follower performance might fade or increase over time. Latent growth curve models can capture such change, be it linear, exponential, or piecewise (in jumps), or conditioned on some exogenous variables (Bollen \& Curran, 2006). 
Predictor repetition. In a one-off treatment, a predictor $x$ affects an outcome $m$, but in subsequent one-off treatments, $x$ affects $m$ differently (i.e., in terms of effect size or direction of the effect). For example, a leader's speeches about task significance might have a strong initial effect (Grant, 2008) but later renditions might not work as well. In other words, the effectiveness of leader behaviors might depend on the history of these behaviors (George \& Jones, 2000).

Predictor-outcome performance spirals. A predictor $x$ affects an outcome $m$, and the changed level of $m$ in turn affects $x$ (i.e., the "simultaneity" problem in econometrics). Selfenforcing spirals are likely frequent in leadership, given that performance as an outcome variable and motivation as a mediating variable tend to be reciprocally related (Antonakis et al., 2010). For example, a leader's charisma motivates followers to perform; they perform better and as a result attribute more charisma to the leader via the "performance-cue effect", which makes followers even more motivated to perform, which again leads to a higher attribution of charisma.

Systemic predictor-variation. A predictor $x$ affects an outcome $m$, but $x$ varies over time and subsequently causes $m$ to change again. For example, research on emotions as a predictor of leadership effectiveness is susceptible to systemic variation (e.g., Groves, 2005), because emotions can change on a by-event basis (Brief \& Weiss, 2002) and so can their impact on outcome variables. Hence, the repeated measurement of $x$ and $m$ is necessary to uncover the temporal structure of emotions.

Although variables can be temporally unstable even in the absence of outside influences, current research neglects systemic variation of predictors. Dimensions of within-variable instability include the magnitude of change, rate of change, durability, and the type of change (discontinuous, periodical, and trending) (Monge, 1990). Emotions and cognitions as the most frequently studied mediators are often inherently varying. Yet, in our sample of articles, one-shot 
measurements of these variables dominated. Thus, the dynamic nature of processes remains ignored leading to potentially false inferences (c.f. Zaheer, Albert \& Zaheer, 1999).

Summary on temporal configurations. The explicit consideration of time in leadership processes is rare. In the reviewed articles, $66 \%$ did not include time lags in their design (Table 2), thereby implicitly assuming a stable equilibrium of effects. False temporal assumptions make for inaccurate conclusions: When leadership studies provide a static snapshot of a temporal phenomenon, the risk of drawing erroneous conclusions and misinforming policy arises. Yet, the inclusion of time presents a tremendous opportunity for advancing knowledge on leadership processes. Below, we lay foundations for time-sensitive leadership research by reflecting on how long it takes for leadership effects to unfold (unfolding time) and how long these effects last (persistence).

\section{Time Lags: Unfolding Time and Persistence of Leadership Effects}

Only if effects are measured after they have unfolded and before they have faded, one can find interpretable results (Mitchell \& James, 2001). Hence, time is a key boundary condition in management research (Whetten, 1989). In general, the more proximal the source and target of an effect are, the faster an effect unfolds. In addition, the higher the target's level of analysis, the slower effects unfold and the longer they last because target constructs at higher levels tend to be more inert and less transient than those at lower levels (illustrated by the downward vertical arrow in Figure 1). In other words, it is more difficult to change an organization than a person. On the basis of our taxonomy (Table 1 and Figure 1), we provide four generic guidelines for modeling time.

Same-level effects. The assessment of unfolding time and persistence is comparatively simple for same-level effects, because the target's (i.e., mediator or outcome) level of analysis 
typically coincides with the source's (i.e., predictor) hierarchical position. The higher the level is, the less immediate is an influence process and the more inert is the target. Thus, same-level effects at a higher level unfold more slowly but last longer than do effects at a lower level.

To illustrate unfolding time and persistence of same-level effects, contrast the effects of a CEO's communication style on organizational performance via organizational morale with those of a team leader's communication style on team performance via team satisfaction.

Organizational morale and organizational performance are relatively inert constructs (c.f. Tripsas \& Gavetti, 2000). Moreover, effects of a CEO's communication style are likely filtered before they affect these outcomes. Therefore, such effects take time to unfold but persist longer than do team or individual-level effects. By comparison, team leaders and their subordinates (a) are usually co-located, (b) interact directly, and (c) communicate relatively frequently. The effect reaches the target directly and unfiltered, and, thus, unfolds relatively fast.

Cross-level effects. The temporality of cross-level effects is less straightforward than that of same-level effects. We suppose that cross-level effects unfold the more slowly, the higher the hierarchical level of the source and the higher the level of analysis of the target are because processes at higher levels do not manifest themselves in outcomes in an immediate way. Additionally, the higher the target's level, the longer an effect persists because higher-level targets' states and actions are more inert relative to those of lower-level targets. Importantly, in cross-level effects, the hierarchical level of the source affects only unfolding time but not persistence. The latter depends uniquely on the target's level (i.e., its inertia).

As an example, compare the effects of a CEO's speech to those of an immediate supervisor's speech on a follower's self-efficacy. On one hand, the influence process of the CEO's speech on the follower, relative to that of a supervisor's speech, is less immediate, 
because the former needs to trickle down across levels. Therefore, the effects of a CEO's speech take longer to unfold than do those of a supervisor's speech. On the other hand, an individual follower's motivation has a basic level of transience, independent of whether a CEO or supervisors influences it. Hence, the persistence of effects caused by a CEO's actions and the persistence of effects caused by a supervisor's actions on the same target are identical, when accounting for the strength of these effects.

As a further illustration of the importance of the level of analysis of the target for understanding the role of time in cross-level effects, consider the effect of a CEO's speech on team efficacy versus the effect of the same speech on the self-efficacy of an individual follower. The effect on team efficacy is more persistent than that on self-efficacy because team efficacy is less transient than self-efficacy. The effect on team efficacy relative to that on self-efficacy also takes longer to unfold because a CEO's speech has a less immediate effect on a higher-level construct like team efficacy than on a lower-level construct like self-efficacy, although the CEO and the team are closer in terms of level of analysis.

\section{Effects of developmental processes versus those of leverage processes. Ceteris} paribus, effects in the process category development (e.g., training) take longer to unfold and persist longer than do effects in the category leveraging (e.g., motivation) (see the horizontal arrow in Figure 1) (Shamir, 2011). Generally speaking, effects of mediators in the development category are more inert, or less bounded in time and space, than are those of mediators in the leveraging category. For example, in order to raise followers' service performance, a leader provides stress training to enhance followers' skills for maintaining positive moods towards customers, or a leader gives a pep talk to cheer employees up. The development of skills takes longer and, hence, has more delayed and persistent effects on followers' affective states than 
does the influence of a pep talk. The effects of the latter may vanish as soon as another affective event takes place (Brief \& Weiss, 2002).

Behavioral versus cognitive and emotional effects. Within the leverage category, effects on the behavior of targets typically take longer to unfold and persist longer than do effects on cognitions or emotions of targets. For example, the effects of positive feedback by a leader on followers' behaviors are more delayed and last longer than do those on followers' moods. In summary, taking into account levels of analysis and the type of leadership process informs researchers about the unfolding time and persistence of effects.

\section{Time Lags: A Cautionary Note}

Having discussed temporal configurations, unfolding time, and persistence of leadership processes, we conclude with a cautionary note. Our point is not that every study must use lags and event-based methods, both of which pose several challenges (Ployhart \& Vandenberg, 2010). Time lags and repeated-measures designs (where a variable is measured at multiple points of time) are not uniformly applicable best practices; depending on the process studied, a crosssectional design may do well too (e.g., when predictors, like leader traits, are stable, and when the phenomenon is in equilibrium). Unlike general calls for longitudinal research (e.g., Jermier \& Kerr, 1997)—for us "longitudinal" means having repeated measures and modeling temporal effects—we call for the explicit treatment of time as a variable in theory and design: Theory must model time and must dictate the use of lagged designs.

Furthermore, we reiterate that temporal order, which results from time lags, is a necessary but not sufficient condition of causality (Antonakis et al., 2010). A very simple example makes this point: If $x$ and $y$ both depend on $z$, using $x$ at time 1 to predict $y$ at time 2 does not solve the endogeneity problem. The variable $z$ will likely correlate with itself over time and thus explain 
part of the relation between $x$ at time 1 and $y$ at time 2; thus, such a lag (i.e., $x$ at time 1 ) is only useful in reducing non-modeled variance in $y$, as long as true exogenous variables, whose coefficients are the only ones that can be interpreted, are used as predictors. An example is the study by Gong, Huang, and Farh (2009) which measured the predictors employees' learning orientation and supervisors' transformational leadership as well as the first-step mediator employee self-efficacy at time 1 and the second-step mediator creativity and the final outcome employee performance at time 2. Omitted variables at the leader or follower level (e.g., employee education, intelligence, or personality) might cause self-efficacy at time 1 and creativity at time 2 and can thus distort the estimate of the effect of self-efficacy on creativity. The example shows that simple time lags are not a panacea for other short-comings, such as omitted variables, that prevent correct causal inferences.

As a further note on repeated measurements, apart from the threat of carry-over effects, both the temporal stability of variables and the stability of effects on these variables are criteria for deciding on repeated-measures designs. Hence, fluctuating variables, such as affect, point to the utility of repeated measurement. If, however, effects on these variables are stable, for example, those of leaders' extraversion as a non-fluctuating trait on followers' affect, repeated measures of the latter should be consistent over time, even in presence of intra-individual emotional fluctuations or when taking into account other effects. Thus, if relations between variables are in equilibrium, there is no need for repeated-measures designs.

In summary, leadership research has so far largely ignored time. By (a) making assumptions about time explicit in theoretical models, (b) considering leadership behaviors as events, (c) allowing for alternative temporal configurations of time, (d) understanding how leadership processes unfold over time and persist, and (e) by the theory-driven use of time lags 
and repeated measures, leadership research can move closer to more accurate models that reflect the temporality of the phenomenon. Treating time explicitly is a must-do for any process theory of leadership. Modeling time alone, however, does not guarantee sound leadership process models. Such models must also take into account that a leadership event may trigger several processes simultaneously that unfold via multiple paths. In the next section, we elaborate why it is often critical to include multiple paths in one model.

\section{MULTI-PATHS PROCESSES: CHALLENGES FOR THEORIZING AND TESTING}

To properly uncover the underlying mechanisms of leadership, alternative channels of influence need to be taken into account. Otherwise, specious mediators might be detected: They look like the "real thing" and give significant results, but do not capture the true causal process. Surprisingly, this serious conceptual risk is largely overlooked. We address this challenge below.

\section{Conceptual Challenge: The "Specious Mediators" Problem}

If a predictor could simultaneously affect other, related constructs in addition to the focal mediator, a variable can falsely appear to be a mediator (i.e., be a specious mediator), if a true causal mediator had been left out in the model. Hence, it is imperative to model and test such mediators simultaneously to identify the causal mechanisms ${ }^{1}$. Importantly, a specious mediator is primarily a conceptual problem, requiring a conceptual solution. Such a solution typically involves modeling multiple paths (see Figure 4).

[Insert Figure 4 about here]

As an example, perceived justice has been found to mediate the impact of monitoring methods on organizational citizenship behavior (OCBs) (Niehoff \& Moorman, 1993). An alternative mediator is trust in the supervisor (Pillai, Schriesheim \& Williams, 1999), which is likely also affected by monitoring and related to perceived justice. Then, if trust but not justice 
perceptions affected OCBs, justice perceptions would appear as a significant mediator if trust is not included in the model. Findings from the model excluding trust are not interpretable because the effect of trust on the parameter estimate for perceived justice is unknown: Perceived justice might be a mediator although likely with less of an impact than the estimate suggests, or worse, it might be a specious mediator. Such a specious mediator can only be uncovered by including true and correlated mediators like trust in the model. Given that a cause like monitoring might have a multitude of proximal effects that are also correlated with trust and perceived justice and which have an effect on OCB too, the risk of ignoring relevant mediators and detecting specious mediators is highly prevalent.

\section{Methodological Challenges in Modeling Multiple Mediation Paths}

Multiple mediation paths are modeled in $37 \%$ of the coded quantitative empirical articles (see Table 2); two methodological challenges likely contribute to this low rate: (a) dealing with same-source bias, when data on the studied variables cannot be obtained from different sources, and (b) identifying exogenous predictors for each mediator. Although we strongly advocate collecting data from different sources and splitting samples, same-source data is sometimes hard to avoid in leadership mediation models. In fact, $79 \%$ of the coded quantitative studies suffer from same-source sampling, which may engender endogeneity bias, that is, biased estimates due to causally incorrect model specification. Furthermore, only $26 \%$ of the studies used exogenous predictors, which also makes most studies prone to endogeneity bias (see Table 2).

To address the methodological challenges of multiple paths in quantitative research, instrumental-variable estimation and sequential experiments can be used. As concerns the first recommendation, although instrumental-variable estimation can deal with same-source bias (Antonakis et al., 2010; Podsakoff, MacKenzie \& Podsakoff, 2012), only 2\% of our coded 
studies used that statistical technique (see Table 2). A critical precondition for instrumental variable procedures is to have at least as many exogenous predictors (i.e., instruments) as endogenous mediators (Wooldridge, 2002) ${ }^{2}$. Instrumental variables can be difficult to find (Podsakoff et al., 2012): They must meet the condition of being invariant to changes in the endogenous variables or their omitted causes. Candidates for instrumental variables include fixed leader traits like personality, intelligence, and age, if there has not been selection on these traits; other potential "instruments" are geographic factors (e.g., temperature), determined factors (e.g., election cycles, latitude), historical factors, or exogenous "shocks" (see Antonakis et al., 2010). Experiments are very useful too because manipulated variables, which are by definition exogenous, can serve as instrumental variables.

With respect to sequential experiments, different cause-effect relationships (e.g., from the predictor to the mediator and from the mediator to the effect) are examined in separate experiments, thus allowing exogenous manipulations of otherwise endogenous variables. For instance, one might first test the effect of structural empowerment on empowering leadership, then that of empowering leadership on follower psychological empowerment, and subsequently, that of follower empowerment on follower performance. Sequential experiments can help establishing causal chains (Eden, Stone-Romero \& Rothstein, 2015; Spencer, Zanna \& Fong, 2005), but they are not a panacea for challenges in testing mediation. The experimental manipulation of the mediator needs to be executed with surgical precision to avoid manipulating more than one mediating process per independent variable. Otherwise, results become noninterpretable due to experimental side-effects on the criterion (Bullock, Green \& Ha, 2010).

Furthermore, an underexplored avenue, which could help shed light on the multi-paths nature of leadership effects is to study its processes in natural settings (Denis, Langley \& Sergi, 
2012). For Pettigrew (1997), processual analysis deals with phenomena that are multi-level and temporally connected and, hence, require holistic explanations. Therefore, research designs originating from naturally occurring data, whether from case studies (Yin, 1994), archival or historiometric data (Simonton, 2003), or other rich descriptive contextually-rooted sources (Conger, 1998) could help uncover proposed process-driven mechanisms of leadership and help build theory. To make robust empirical inference, as with quantitative research, there are many methodological issues that must be considered in pattern matching, whether these relations are ultimately quantified or not (Maxwell, 2010); these issues concern sampling (cf. Denrell, 2003) to ensure that outcomes vary via contrasting cases of, for example, high and low performing teams (cf. Eisenhardt \& Graebner, 2007), and valid coding and classification of data so as to ensure replicability, reliability, and trustworthiness of findings among other issues (Patton, 2002).

To sum up, process-based thinking about leadership requires paying attention to two largely ignored aspects of theorizing: First, modeling temporal configurations, and second, taking into account that multiple processes can evolve simultaneously. We are not aware of a leadership theory that sufficiently addresses these challenges. In the next section, we demonstrate how the use of our taxonomy (Table 1) can help in developing and testing process theories of leadership.

\section{DEVELOPING PROCESS THEORIES OF LEADERSHIP}

To help stimulate process thinking, we present four reflection points and illustrate their usage with a fictitious example of a field study on empowering leadership. Empowering leadership is a fitting candidate for a process theory because "empowering" points to action in flux and an emerging process (c.f. Tsoukas \& Chia, 2002). Our fictitious study can help 
advancing research from addressing the input-output question of "does empowering team leadership have a causal effect on team performance?" to speaking to process questions. Such questions include, if effects exist, "what causes empowering leadership (i.e., it is an endogenous construct) ${ }^{3}$ ?", "how, or through which paths and how fast do they unfold and how long do they last?" Despite the conceptual piece by Conger and Kanungo (1988) and much published research (e.g., Logan \& Ganster, 2007; Spreitzer, 1995; Stewart, 2006), what determines empowering leadership, how and for how long empowering leadership affects outcomes is not well understood (House, 1996; Zhang \& Bartol, 2010). Some research has addressed individual-level leverage processes, such as meaning, self-determination, impact, psychological empowerment, creative process engagement, and intrinsic motivation (Spreitzer, 1995; Zhang \& Bartol, 2010). Yet, studies on team-level mediators, such as information sharing and team efficacy (e.g., Srivastava, Bartol \& Locke, 2006), are rare.

With regard to the field of leadership in general, opportunities for developing process theories abound. Figure 3 points to developmental and context-shaping processes as two understudied domains. Apart from researching in understudied domains, both pure input-output studies that largely ignore processes and moderation studies invite reflection about the mechanisms behind their presumed effects. Moderating effects can point to mediating variables that both the moderator and the predictor affect (Baron \& Kenny, 1986). Once researchers have settled on a leadership process to be studied, they have to address the complexity of these processes, which, for example, operate through multiple paths. Complex phenomena require complex research questions, and the answer to these questions might be models that are perhaps theoretically sound but not testable. 
To balance conceptual complexity and empirical feasibility, we suggest four reflection points on the basis of our taxonomy: (1) a within-cell check for similar processes at the same level, (2) across-cells checks for similar processes at other levels or alternative processes in another type-of-process category, (3) a plausibility check for completeness in inputs, processes, and outputs, and (4) a check on temporal specification. On one hand, going through the four checks helps determining variables to be included but, equally important, also variables to be excluded from empirical testing to avoid throwing in the "kitchen sink" (cf. Green, Tonidandel \& Cortina, 2016). On the other hand, the four checks raise awareness about competing explanations for leadership effects and limitations resulting from ignoring these explanations.

\section{Reflection Point 1: Within-Cell Check for Similar Processes at the Same Level}

Initially, the leadership process of interest is placed in the taxonomy. Researchers determine which type of process the focal mediator represents (i.e., resource development or leverage) and at which level of analysis (e.g., team level) it takes places. A comparison of the mediator to other mediators in the same cell follows. This comparison, which is similar to embedding a variable into a nomological network of related constructs, can result in more precise theorizing by ensuring the fit between the supposed process and the mediator. Moreover, this check can detect important alternative mediators while ruling out irrelevant ones, thereby preventing the discovery of specious mediators. Lastly, this check ensures that the mediator variable is conceptually not too close to the predictor or the outcome, thus mitigating the risk of studying known, obvious, or near tautological processes.

Applied to our example, we decide that team-level leverage processes of empowering leadership are promising areas of inquiry. We settle on team empowerment climate as a candidate for mediating effects of empowering leadership on team performance. Team 
empowerment climate, which refers to the extent that empowerment is expected, supported, and rewarded in the team, falls into the leverage cell at the team level in Table 1. Another mediator in this cell is team efficacy as the shared belief that the team can complete its projects. Comparing both variables reveals that empowerment climate has specific motivating effects for pushing team members in the direction of empowered behaviors, whereas team efficacy has a more general motivating effect that raises effort and persistence. Weighing the conceptual necessity and empirical cost of including team efficacy into the study design, we retain team efficacy due to its potential relation to team empowerment climate. We also question whether empowerment climate is not a too obvious candidate for mediating effects of empowering leadership. We decide, however, not to assume an automatic relationship between empowering leadership as a behavioral construct and empowerment climate as a perceptual construct.

\section{Reflection Point 2: Across-Cells Checks for Processes at Other Levels and of Alternative Types}

Whereas the within-cell check enhances theoretical precision, across-cells comparisons increase comprehensiveness and help identify alternative explanations. The vertical across-cells check aids in spotting potential cross-level processes or homologous processes at other levels. This check also stimulates considerations about the level of analysis for a given process. What is thought to be a process occurring between individual leaders and individual followers might turn out to be a team-level process, in particular, when followers influence each other. Or, what is thought be a single-level process might be a multi-level process, whereby, for instance, an individual-level process can only take place in specific team contexts.

The horizontal across-cells check primarily serves to raise awareness about the interplay between the development of factors contributing to performance, such as skills, and their 
leverage, thus aiding in building comprehensive leadership mediation models. Effects of mediators in the leverage category are conditional on the presence of a minimum level of skills, knowledge, and abilities to be leveraged. Although reflection about process models should be sensitive to development and leverage mediators, the simultaneous examination of these mediators is not a must. Rather, the conditions have to be in place for development or leverage mediators to operate.

For our example of empowering leadership, a vertical across-cells check suggests that for the causal chain from empowering leadership to team empowerment climate and ultimately team performance there might be a homologous process at the individual level. We, therefore, ensure measuring relevant constructs at the individual level too. The question also arises whether effects of empowering leadership at the team level are dependent on enabling conditions at the organizational level, for example, in terms of organizational structure (Kanter, 1977). In our study, the teams are nested within one organization. Thus, we cannot assess enabling conditions at a higher level, which is a limitation and might help explain potential null findings, although we could feasibly model departmental-level differences.

Furthermore, the horizontal across-cells check invites consideration of whether developmental processes play a role in addition to the leverage processes mediated by team empowerment climate. For example, might skills for initiative-taking that leaders have developed in team members contribute to both empowerment climate and team performance? We cannot rule this possibility out, and one potential solution could be a panel design, that is, measuring empowering leadership, empowerment climate, and performance at more than one point in time. 


\section{Reflection Point 3: Plausibility Check for Completeness in Inputs, Processes, and Outputs}

In this check, researchers evaluate their process model through two complementary approaches: (a) "Back-tracking", an inductive approach, and (b) "forward-tracking", a deductive approach. In back-tracking, the starting point is the outcome (e.g., team performance), from which researchers seek to uncover proximal causes (cf. Juran, 1992); these can include mediators as well as distal causes, such as exogenous predictors. Back-tracking moves from the right of the input-process-output logic to the left, thus, fostering multi-causal reasoning. When studying effects of leader behaviors or styles, back-tracking points to three common challenges: (1) Taking into account overlapping conceptualizations of these behaviors, such as those of servant leadership and empowering leadership (Amundsen \& Martinsen, 2014; Van Dierendonck, 2011); (2) embedding an isolated leadership behavior into a broader theory of leadership, such as the full-range theory of leadership (Antonakis \& House, 2014); and, (3) considering that leadership behaviors or styles are endogenous predictors that result from other factors, such as leader traits.

In contrast, in "forward-tracking" the starting point is a cause, and researchers search immediate (i.e., mediators) and remote outcomes (i.e., criteria) of this cause (cf. Durand \& Vaara, 2009). Forward-tracking proceeds from the left of the input-process-output logic to the right, thus driving multi-mediator and multi-criterion reasoning. Forward-tracking is akin to deductive reasoning that challenges existing assumptions about processes (cf. Alvesson \& Sandberg, 2011). In tandem, back-tracking and forward tracking can balance holistically oriented grand theorizing with more micro thinking about processes or mechanisms (c.f. Weber, 2006).

In the case of empowering leadership, we use back-tracking to check if team performance is caused by empowerment climate even when considering competing causes and if the latter is caused by factors other than empowering leadership. Empowerment climate, for instance, might 
also result from instrumental leadership, such that leaders organize work in a way that facilitates team performance, or because of other aspects of transformational leadership (Antonakis \& House, 2014). We decide not to assess servant leadership given its conceptual similarity, to the point of redundancy, to empowering leadership and because our focus is on process testing rather than construct validation. Moreover, to embed empowering leadership with other leader behaviors upon which its effects might be based, we decide measuring and controlling for transformational leadership, including "individualized consideration" even if similar to empowering leadership as a convergence check, transactional, and instrumental leader behaviors.

Finally, using forward-tracking, we reflect on whether empowering leadership influences proximal outcomes other than empowerment climate and distal outcomes other than team performance. For example, empowering leadership should also affect team morale, which, in turn, is likely related to team performance. Hence, we include morale as a competing mediator in our model.

\section{Reflection Point 4: Check on Temporal Specification}

In this check, researchers specify how the modeled constructs evolve over time. Initially, researchers determine temporal construct attributes and temporal configurations of the relationships among the constructs. For example, do effects unfold immediately, are they in a stable equilibrium, or is the temporal configuration more complex (e.g., unstable predictoroutcome relationship or systemic predictor variation)? Next, the taxonomy helps modeling unfolding time and persistence of effects by offering these insights: (a) Processes at lower levels unfold faster and persist less than do those at higher levels; (b) mediators and outcomes at higher levels of analysis are more inert than are those at lower levels (c) in terms of different types of processes, effects due to resource development take and last longer than do leverage effects; and 
(d) within the leverage category behavioral processes unfold more slowly and persist longer than do cognitive and emotional processes.

For our example of empowering leadership, the question of the temporality of constructs and that of the relationships among them point to current limits in understanding empowering leadership. Is empowering leader behavior an ongoing activity, which a person-whole measure might capture, or a series of repeated behaviors, which would require an event-by-event or person-part measure? Team empowerment climate is a relatively inert construct as is team performance given that stable contextual forces restrict the variance of the latter. In terms of relationships among variables, effects of empowering leadership behaviors on empowerment climate are more likely, the more consistently leaders engage in these behaviors. Moreover, effects of empowering leadership on team empowerment climate and those of the latter on team performance should unfold relatively slowly. Hence, cross-sectional relationships between these pairs of variables might be weaker than longitudinal ones. Therefore, a relatively long time lag (e.g., three to twelve months) is appropriate for measuring empowering leadership, team empowerment climate, and team performance.

Overall, the above example shows how the four reflection points can help developing a solid theoretical foundation of a leadership process. By leading to more accurate and more comprehensive models, the reflection points also inform decisions about study designs and measures, including which constructs to measure, and when and how often to measure them.

\section{CONCLUSION: THE FUTURE OF LEADERSHIP PROCESS RESEARCH}

Before making concluding comments, we highlight three challenges that our review reveals and that our reflection points help address: Future leadership process research needs to be 
(a) multi-process, (b) multi-level, and (c) time-sensitive to allow for enhanced scientific understanding and practical relevance.

\section{Constructing Multi-Process Models}

Future leadership process research takes into account that leadership produces effects via multiple paths. For instance, not only socialized but also personalized identification mediates effects of leader charisma on follower performance. A within-cell check in our taxonomy clarifies the need for including both constructs as mediators within one model (see Kark, Shamir \& Chen, 2003). Moreover, predictors of leadership often operate in tandem, and, thus, modeling similar but different leadership styles simultaneously prevents the under-specification of models. Future research must correct, for example, the bad practice of modeling the effects of transformational leadership without accounting for transactional leadership (e.g., Gong et al., 2009; Kovjanic, Schuh \& Jonas, 2013)—although the former is supposed to "build-on" and "augment" the latter (Hater \& Bass, 1988) —as well as instrumental forms of leadership too (Antonakis \& House, 2014).

\section{Building Multi-Level Models of Leadership}

Future leadership process research builds multi-level models that reflect the multi-layered reality of leadership in organizations (c.f. Heath \& Sitkin, 2001). Conducting cross-level checks in our taxonomy aids in building such models, which offer more comprehensive views of leadership effects and can resolve contradictions in the literature. For instance, leader behaviors can directly influence followers at the individual level but they also create structures that serve as "substitutes for leadership" at the team or organizational level. Thus, the comprehensive examination of "substitutes for leadership" and leadership might show how the former do not replace leadership, but are a process through which leadership operates. 


\section{Developing Time-Sensitive Models of Leadership}

Future leadership process research develops theories of how effects unfold over time and space. Such theories inform the choice of time lags, thereby avoiding biased model estimates. Our guidelines for modeling time serve as a first step towards temporal specification in theory and empirics. Equally important, temporal specification of the unfolding time and persistence of leadership effects helps practitioners determining the timing of their actions. For example, leaders might consider balancing the short-term effects of appealing to followers' emotions with the long-term effects of shaping the work context to drive performance in both the near and distant future.

\section{Concluding Comments}

The purpose of our article was to review mediation research on leadership and provide foundations for developing more complete process theories of leadership. We trust that we will stimulate research on leadership that is true to its definition as a social and goal-directed influence process that unfolds in space and time. We recognize that we have set an ambitious research agenda and we look forward to seeing research that will rise to our challenge. To conclude, as Shamir (2011) wisely said in his eponymous article: "Leadership takes time.” So too will the construction of more complete process models of leadership. 


\section{REFERENCES}

Alvesson, M., \& Sandberg, J. 2011. Generating research questions through problematization. Academy of Management Review, 36(2): 247-271.

Amundsen, S., \& Martinsen, Ø. L. 2014. Empowering leadership: Construct clarification, conceptualization, and validation of a new scale. The Leadership Quarterly, 25(3): 487511.

Ancona, D. G., Goodman, P. S., Lawrence, B. S., \& Tushman, M. L. 2001. Time: A new research lens. Academy of Management Review, 26(4): 645-663.

Antonakis, J., Bendahan, S., Jacquart, P., \& Lalive, R. 2010. On making causal claims: A review and recommendations. The Leadership Quarterly, 21(6): 1086-1120.

Antonakis, J., Day, D. V., \& Schyns, B. 2012. Leadership and individual differences: At the cusp of a renaissance. The Leadership Quarterly, 23(4): 643-650.

Antonakis, J., \& House, R. J. 2014. Instrumental leadership: Measurement and extension of transformational-transactional leadership theory. The Leadership Quarterly, 25: 746-771.

Ayoko, O. B., \& Chua, E. L. 2014. The importance of transformational leadership behaviors in team mental model similarity, team efficacy, and intra-team conflict. Group \& Organization Management, 39(5): 504-531.

Balkundi, P., \& Kilduff, M. 2006. The ties that lead: A social network approach to leadership. The Leadership Quarterly, 17(4): 419-439.

Baron, R. M., \& Kenny, D. A. 1986. The moderator-mediator variable distinction in social psychological research: Conceptual, strategic, and statistical considerations. Journal of Personality and Social Psychology, 51(6): 1173.

Barrick, M. R., Thurgood, G. R., Smith, T. A., \& Courtright, S. H. 2015. Collective organizational engagement: Linking motivational antecedents, strategic implementation, and firm performance. Academy of Management Journal, 58(1): 111-135.

Bergh, D. D., \& Perry, J. 2006. Some predictors of SMJ article impact. Strategic Management Journal, 27(1): 81-100.

Beyer, J. M., Chattopadhyay, P., George, E., Glick, W. H., \& Pugliese, D. 1997. The selective perception of managers revisited. Academy of Management Journal, 40(3): 716-737. 
Bezuijen, X. M., Dam, K., Berg, P. T., \& Thierry, H. 2010. How leaders stimulate employee learning: A leader-member exchange approach. Journal of Occupational and Organizational Psychology, 83(3): 673-693.

Blumberg, M., \& Pringle, C. D. 1982. The missing opportunity in organizational research: Some implications for a theory of work performance. Academy of Management Review, 7(4): 560-569.

Bollen, K. A. 1996. An alternative two stage least squares (2SLS) estimator for latent variable equations. Psychometrika, 61(1): 109-121.

Bollen, K. A. 2012. Instrumental variables in sociology and the social sciences. Annual Review of Sociology, 38: 37-72.

Bollen, K. A., \& Curran, P. J. 2006. Latent curve models: A structural equation perspective. Hoboken, N.J.: Wiley-Interscience.

Brief, A. P., \& Weiss, H. M. 2002. Organizational behavior: Affect in the workplace. Annual Review of Psychology, 53(1): 279-307.

Bullock, J. G., Green, D. P., \& Ha, S. E. 2010. Yes, but what's the mechanism?(don't expect an easy answer). Journal of Personality and Social Psychology, 98(4): 550.

Carmeli, A., Schaubroeck, J., \& Tishler, A. 2011. How CEO empowering leadership shapes top management team processes: Implications for firm performance. The Leadership Quarterly, 22(2): 399-411.

Cavazotte, F., Moreno, V., \& Hickmann, M. 2012. Effects of leader intelligence, personality and emotional intelligence on transformational leadership and managerial performance. The Leadership Quarterly, 23(3): 443-455.

Collins, C. J., \& Clark, K. D. 2003. Strategic human resource practices, top management team social networks, and firm performance: The role of human resource practices in creating organizational competitive advantage. Academy of Management Journal, 46(6): 740-751.

Conger, J. A. 1998. Qualitative research as the cornerstone methodology for understanding leadership. The Leadership Quarterly, 9(1): 107-121.

Conger, J. A., \& Kanungo, R. N. 1988. The empowerment process: Integrating theory and practice. Academy of Management Review, 13(3): 471-482. 
Crossley, C. D., Cooper, C. D., \& Wernsing, T. S. 2013. Making things happen through challenging goals: Leader proactivity, trust, and business-unit performance. Journal of Applied Psychology, 98(3): 540.

Davis, G. F., \& Marquis, C. 2005. Prospects for organization theory in the early twenty-first century: Institutional fields and mechanisms. Organization Science, 16(4): 332-343.

Day, D. V. 2014. 3 Time and leadership. Time and Work, Volume 2: How Time Impacts Groups, Organizations and Methodological Choices: 30.

Day, D. V., \& Dragoni, L. 2015. Leadership development: An outcome-oriented review based on time and levels of analyses. Annual Review of Organizational Psychology and Organizational Behavior, 2(1): 133-156.

Day, D. V., Gronn, P., \& Salas, E. 2004. Leadership capacity in teams. The Leadership Quarterly, 15(6): 857-880.

Day, D. V., \& Lord, R. G. 1988. Executive leadership and organizational performance: Suggestions for a new theory and methodology. Journal of Management, 14(3): 453-464.

DeChurch, L. A., Hiller, N. J., Murase, T., Doty, D., \& Salas, E. 2010. Leadership across levels: Levels of leaders and their levels of impact. The Leadership Quarterly, 21(6): 1069-1085.

Denis, J.-L., Langley, A., \& Sergi, V. 2012. Leadership in the plural. The Academy of Management Annals, 6(1): 211-283.

Denrell, J. 2003. Vicarious learning, undersampling of failure, and the myths of management. Organization Science, 14(3): 227-243.

Dinh, J. E., Lord, R. G., Gardner, W. L., Meuser, J. D., Liden, R. C., \& Hu, J. 2014. Leadership theory and research in the new millennium: Current theoretical trends and changing perspectives. The Leadership Quarterly, 25(1): 36-62.

Dormann, C., \& Griffin, M. A. 2015. Optimal time lags in panel studies. Psychological Methods, 20(4): 489.

Druskat, V. U., \& Wolff, S. B. 1999. Effects and timing of developmental peer appraisals in selfmanaging work groups. Journal of Applied Psychology, 84(1): 58.

Dubin, R. 1976. Theory building in applied areas. Handbook of Industrial and Organizational Psychology, 17: 39.

Durand, R., \& Vaara, E. 2009. Causation, counterfactuals, and competitive advantage. Strategic Management Journal, 30(12): 1245-1264. 
Eden, D., Stone-Romero, E. F., \& Rothstein, H. R. 2015. Synthesizing results of multiple randomized experiments to establish causality in mediation testing. Human Resource Management Review, 25(4): 342-351.

Edmondson, A. C. 2003. Speaking up in the operating room: How team leaders promote learning in interdisciplinary action teams. Journal of Management Studies, 40(6): 1419-1452.

Eisenhardt, K. M., \& Graebner, M. E. 2007. Theory building from cases: Opportunities and challenges. Academy of Management Journal, 50(1): 25-32.

Finkelstein, S., Hambrick, D. C., \& Cannella, A. A. 2009. Strategic leadership: Theory and research on executives, top management teams, and boards: Oxford University Press, USA.

Fredrickson, B. L., \& Kahneman, D. 1993. Duration neglect in retrospective evaluations of affective episodes. Journal of Personality and Social Psychology, 65(1): 45.

George, J. M., \& Jones, G. R. 2000. The role of time in theory and theory building. Journal of Management, 26(4): 657-684.

Gibson, C. B., \& Birkinshaw, J. 2004. The antecedents, consequences, and mediating role of organizational ambidexterity. Academy of Management Journal, 47(2): 209-226.

Golden, B. R. 1992. Research notes. The past is the past-or is it? The use of retrospective accounts as indicators of past strategy. Academy of Management Journal, 35(4): 848-860.

Gong, Y., Huang, J.-C., \& Farh, J.-L. 2009. Employee learning orientation, transformational leadership, and employee creativity: The mediating role of employee creative self-efficacy. Academy of Management Journal, 52(4): 765-778.

Grant, A. M. 2008. The significance of task significance: Job performance effects, relational mechanisms, and boundary conditions. Journal of Applied Psychology, 93(1): 108-124.

Green, J. P., Tonidandel, S., \& Cortina, J. M. 2016. Getting Through the Gate Statistical and Methodological Issues Raised in the Reviewing Process. Organizational Research Methods: 1094428116631417.

Groves, K. S. 2005. Linking leader skills, follower attitudes, and contextual variables via an integrated model of charismatic leadership. Journal of Management, 31(2): 255-277.

Hackman, J. R., \& Wageman, R. 2005. A theory of team coaching. Academy of Management Review, 30(2): 269-287. 
Hater, J. J., \& Bass, B. M. 1988. Superiors' evaluations and subordinates' perceptions of transformational and transactional leadership. Journal of Applied Psychology, 73(4): 695.

Heath, C., \& Sitkin, S. B. 2001. Big-B versus Big-O: What is organizational about organizational behavior? Journal of Organizational Behavior, 22(1): 43-58.

Heimeriks, K. H., \& Duysters, G. 2007. Alliance capability as a mediator between experience and alliance performance: An empirical investigation into the alliance capability development process. Journal of Management Studies, 44(1): 25-49.

Hernandez, M., Eberly, M. B., Avolio, B. J., \& Johnson, M. D. 2011. The loci and mechanisms of leadership: Exploring a more comprehensive view of leadership theory. The Leadership Quarterly, 22(6): 1165-1185.

Higgins, M. C., \& Kram, K. E. 2001. Reconceptualizing mentoring at work: A developmental network perspective. Academy of Management Review, 26(2): 264-288.

Hill, N. S., Kang, J. H., \& Seo, M.-G. 2014. The interactive effect of leader-member exchange and electronic communication on employee psychological empowerment and work outcomes. The Leadership Quarterly, 25(4): 772-783.

Hiller, N. J., DeChurch, L. A., Murase, T., \& Doty, D. 2011. Searching for outcomes of leadership: A 25-year review. Journal of Management, 37(4): 1137-1177.

Ho, V. T., \& Pollack, J. M. 2014. Passion isn't always a good thing: Examining entrepreneurs' network centrality and financial performance with a dualistic model of passion. Journal of Management Studies, 51(3): 433-459.

Hoffman, E. L., \& Lord, R. G. 2013. A taxonomy of event-level dimensions: Implications for understanding leadership processes, behavior, and performance. The Leadership Quarterly, 24(4): 558-571.

Hogan, R., \& Kaiser, R. B. 2005. What we know about leadership. Review of General Psychology, 9(2): 169.

Houghton, J. D., Pearce, C. L., Manz, C. C., Courtright, S., \& Stewart, G. L. 2015. Sharing is caring: Toward a model of proactive caring through shared leadership. Human Resource Management Review, 25(3): 313-327.

House, R. J. 1996. Path-goal theory of leadership: Lessons, legacy, and a reformulated theory. The Leadership Quarterly, 7(3): 323-352. 
Hunter, E. M., Neubert, M. J., Perry, S. J., Witt, L., Penney, L. M., \& Weinberger, E. 2013.

Servant leaders inspire servant followers: Antecedents and outcomes for employees and the organization. The Leadership Quarterly, 24(2): 316-331.

Hunter, S. T., Bedell-Avers, K. E., \& Mumford, M. D. 2007. The typical leadership study: Assumptions, implications, and potential remedies. The Leadership Quarterly, 18(5): 435446.

Hutzschenreuter, T., \& Kleindienst, I. 2006. Strategy-process research: What have we learned and what is still to be explored. Journal of Management, 32(5): 673-720.

Jawahar, I. 2010. The mediating role of appraisal feedback reactions on the relationship between rater feedback-related behaviors and ratee performance. Group \& Organization Management, 35(4): 494-526.

Jermier, J. M., \& Kerr, S. 1997. "Substitutes for leadership: Their meaning and measurement"Contextual recollections and current observations. The Leadership Quarterly, 8(2): 95-101.

Juran, J. M. 1992. Juran on quality by design: The new steps for planning quality into goods and services: Simon and Schuster.

Kanter, R. M. 1977. Men and women of the corporation: Basic books.

Kark, R., Shamir, B., \& Chen, G. 2003. The two faces of transformational leadership: Empowerment and dependency. Journal of Applied Psychology, 88(2): 246.

Kearney, E., Gebert, D., \& Voelpel, S. C. 2009. When and how diversity benefits teams: The importance of team members' need for cognition. Academy of Management Journal, 52(3): 581-598.

Kellett, J. B., Humphrey, R. H., \& Sleeth, R. G. 2006. Empathy and the emergence of task and relations leaders. The Leadership Quarterly, 17(2): 146-162.

Kirkman, B. L., Tesluk, P. E., \& Rosen, B. 2004. The impact of demographic heterogeneity and team leader-team member demographic fit on team empowerment and effectiveness. Group \& Organization Management, 29(3): 334-368.

Kovjanic, S., Schuh, S. C., \& Jonas, K. 2013. Transformational leadership and performance: An experimental investigation of the mediating effects of basic needs satisfaction and work engagement. Journal of Occupational and Organizational Psychology, 86(4): 543-555. 
Krasikova, D. V., Green, S. G., \& LeBreton, J. M. 2013. Destructive leadership: A theoretical review, integration, and future research agenda. Journal of Management, 39(5): 13081338.

Landis, J. R., \& Koch, G. G. 1977. The measurement of observer agreement for categorical data. Biometrics: 159-174.

Langley, A., Smallman, C., Tsoukas, H., \& Van de Ven, A. H. 2013. Process studies of change in organization and management: Unveiling temporality, activity, and flow. Academy of Management Journal, 56(1): 1-13.

Leroy, H., Dierynck, B., Anseel, F., Simons, T., Halbesleben, J. R., McCaughey, D., Savage, G. T., \& Sels, L. 2012. Behavioral integrity for safety, priority of safety, psychological safety, and patient safety: A team-level study. Journal of Applied Psychology, 97(6): 1273.

Logan, M. S., \& Ganster, D. C. 2007. The effects of empowerment on attitudes and performance: The role of social support and empowerment beliefs. Journal of Management Studies, 44(8): 1523-1550.

Lord, R. G., Binning, J. F., Rush, M. C., \& Thomas, J. C. 1978. The effect of performance cues and leader behavior on questionnaire ratings of leadership behaviorr. Organizational Behavior and Human Performance, 21(1): 27-39.

Lyons, J. B., \& Schneider, T. R. 2009. The effects of leadership style on stress outcomes. The Leadership Quarterly, 20(5): 737-748.

Maxwell, J. A. 2010. Using Numbers in Qualitative Research. Qualitative Inquiry, 16(6): 475482.

Meuser, J. D., Gardner, W. L., Dinh, J. E., Hu, J., Liden, R. C., \& Lord, R. G. 2016. A Network Analysis of Leadership Theory: The Infancy of Integration. Journal of Management.

Mitchell, T. R., \& James, L. R. 2001. Building better theory: Time and the specification of when things happen. Academy of Management Review, 26(4): 530-547.

Monge, P. R. 1990. Theoretical and analytical issues in studying organizational processes. Organization Science, 1(4): 406-430.

Morgeson, F. P., Mitchell, T. R., \& Liu, D. 2015. Event System Theory: An event-oriented approach to the organizational sciences. Academy of Management Review, 40(4): 515-537. 
Ngo, H. y., Foley, S., \& Loi, R. 2009. Family friendly work practices, organizational climate, and firm performance: A study of multinational corporations in Hong Kong. Journal of Organizational Behavior, 30(5): 665-680.

Niehoff, B. P., \& Moorman, R. H. 1993. Justice as a mediator of the relationship between methods of monitoring and organizational citizenship behavior. Academy of Management Journal, 36(3): 527-556.

Oldham, G. R., Hackman, J. R., Smith, K., \& Hitt, M. 2005. How job characteristics theory happened. The Oxford handbook of management theory: The process of theory development.

Olson, B. J., Parayitam, S., \& Bao, Y. 2007. Strategic decision making: The effects of cognitive diversity, conflict, and trust on decision outcomes. Journal of Management, 33(2): 196222.

Patton, M. Q. 2002. Qualitative research and evaluation methods (3 ed.). Thousand Oaks, Calif.: Sage Publications.

Pettigrew, A. M. 1997. What is a processual analysis? Scandinavian Journal of Management, 13(4): 337-348.

Piccolo, R. F., \& Colquitt, J. A. 2006. Transformational leadership and job behaviors: The mediating role of core job characteristics. Academy of Management Journal, 49(2): 327340.

Pillai, R., Schriesheim, C. A., \& Williams, E. S. 1999. Fairness perceptions and trust as mediators for transformational and transactional leadership: A two-sample study. Journal of Management, 25(6): 897-933.

Ployhart, R. E., \& Vandenberg, R. J. 2010. Longitudinal research: The theory, design, and analysis of change. Journal of Management, 36(1): 94-120.

Podsakoff, P. M., MacKenzie, S. B., \& Podsakoff, N. P. 2012. Sources of method bias in social science research and recommendations on how to control it. Annual Review of Psychology, 63: 539-569.

Rousseau, D. M., \& Fried, Y. 2001. Location, location, location: Contextualizing organizational research. Journal of Organizational Behavior, 22(1): 1-13.

Senge, P. M. 2014. The fifth discipline fieldbook: Strategies and tools for building a learning organization: Crown Business. 
Shamir, B. 2011. Leadership takes time: Some implications of (not) taking time seriously in leadership research. The Leadership Quarterly, 22(2): 307-315.

Shaver, J. M. 2005. Testing for mediating variables in management research: Concerns, implications, and alternative strategies. Journal of Management, 31(3): 330-353.

Shipp, A. J., \& Cole, M. S. 2015. Time in individual-level organizational studies: What is it, how is it used, and why isn't it exploited more often? Annual Review of Organizational Psychology and Organizational Behavior, 2(1): 237-260.

Simonton, D. K. 2003. Qualitative and Quantitative Analyses of Historical Data. Annual Review of Psychology, 54: 617-640.

Somech, A., \& Khalaili, A. 2014. Team boundary activity its mediating role in the relationship between structural conditions and team innovation. Group \& Organization Management, 39(3): 274-299.

Spencer, S. J., Zanna, M. P., \& Fong, G. T. 2005. Establishing a causal chain: Why experiments are often more effective than mediational analyses in examining psychological processes. Journal of Personality and Social Psychology, 89(6): 845.

Spreitzer, G. M. 1995. Psychological empowerment in the workplace: Dimensions, measurement, and validation. Academy of Management Journal, 38(5): 1442-1465.

Srivastava, A., Bartol, K. M., \& Locke, E. A. 2006. Empowering leadership in management teams: Effects on knowledge sharing, efficacy, and performance. Academy of Management Journal, 49(6): 1239-1251.

Stewart, G. L. 2006. A Meta-Analytic Review of Relationships Between Team Design Features and Team Performance. Journal of Management, 32(1): 29-55.

Sydow, J., Lerch, F., Huxham, C., \& Hibbert, P. 2011. A silent cry for leadership: Organizing for leading (in) clusters. The Leadership Quarterly, 22(2): 328-343.

Tripsas, M., \& Gavetti, G. 2000. Capabilities, cognition, and inertia: Evidence from digital imaging. Strategic Management Journal, 21(10-11): 1147-1161.

Tsoukas, H., \& Chia, R. 2002. On organizational becoming: Rethinking organizational change. Organization Science, 13(5): 567-582.

Uhl-Bien, M., Riggio, R. E., Lowe, K. B., \& Carsten, M. K. 2014. Followership theory: A review and research agenda. The Leadership Quarterly, 25(1): 83-104. 
Uzzi, B. 1997. Social structure and competition in interfirm networks: The paradox of embeddedness. Administrative Science Quarterly: 35-67.

Van de Ven, A. H. 1992. Suggestions for studying strategy process: A research note. Strategic Management Journal, 13(5): 169-188.

Van Dierendonck, D. 2011. Servant leadership: A review and synthesis. Journal of Management, 37(4): 1228-1261.

Van Knippenberg, D., \& Sitkin, S. B. 2013. A critical assessment of charismatictransformational leadership research: Back to the drawing board? The Academy of Management Annals, 7(1): 1-60.

Vera, D., \& Crossan, M. 2004. Strategic leadership and organizational learning. Academy of Management Review, 29(2): 222-240.

Weber, K. 2006. From nuts and bolts to toolkits theorizing with mechanisms. Journal of Management Inquiry, 15(2): 119-123.

Whetten, D. A. 1989. What constitutes a theoretical contribution? Academy of Management Review, 14(4): 490-495.

Williams, E. A., Scandura, T. A., \& Gavin, M. 2009. Understanding team-level career mentoring by leaders and its effects on team-source learning: The effects of intra-group processes. Human Relations.

Wooldridge, J. M. 2002. Econometric analysis of cross section and panel data. Cambridge, MA: MIT Press.

Wright, P. M., \& Snell, S. A. 1991. Toward an integrative view of strategic human resource management. Human Resource Management Review, 1(3): 203-225.

Yammarino, F. J., Dionne, S. D., Chun, J. U., \& Dansereau, F. 2005. Leadership and levels of analysis: A state-of-the-science review. The Leadership Quarterly, 16(6): 879-919.

Yin, R. K. 1994. Case study research: Design and methods. Thousand Oaks, CA: Sage Publications.

Yukl, G. 2008. How leaders influence organizational effectiveness. The Leadership Quarterly, 19(6): 708-722.

Zaccaro, S. J., Connelly, S., Repchick, K. M., Daza, A. I., Young, M. C., Kilcullen, R. N., Gilrane, V. L., Robbins, J. M., \& Bartholomew, L. N. 2015. The influence of higher order 
cognitive capacities on leader organizational continuance and retention: The mediating role of developmental experiences. The Leadership Quarterly, 26(3): 342-358.

Zaheer, S., Albert, S., \& Zaheer, A. 1999. Time scales and organizational theory. Academy of Management Review, 24(4): 725-741.

Zhang, H., Kwong Kwan, H., Everett, A. M., \& Jian, Z. 2012. Servant leadership, organizational identification, and work-to-family enrichment: The moderating role of work climate for sharing family concerns. Human Resource Management, 51(5): 747-767.

Zhang, X., \& Bartol, K. M. 2010. Linking empowering leadership and employee creativity: The influence of psychological empowerment, intrinsic motivation, and creative process engagement. Academy of Management Journal, 53(1): 107-128.

Zhu, W., Chew, I. K., \& Spangler, W. D. 2005. CEO transformational leadership and organizational outcomes: The mediating role of human-capital-enhancing human resource management. The Leadership Quarterly, 16(1): 39-52. 


\section{NOTES}

${ }^{1}$ Not modeling multiple paths would be feasible if the researcher knows, for whatever reason, that an "instrument" $(x)$ of the mediator $m l$ directly affects only $m l$ and no other construct that is correlated with $m l$ (an instrument is an exogenous variable that does not correlate with the regression's error term). Suppose that the true model is $x \rightarrow m l \rightarrow y$ and that $m 1$ is endogenous with respect to $y$ because both depend on an omitted cause $q$ (endogenous means that $m l$ correlates with the disturbance of $y$, in this case due to $q$ ). The instrumental variable estimator (Antonakis et al., 2010) like two-stage least squares, uses the exogenous part of the variance in $x$ to isolate the true effect of $m l$ on $y$ and will provide a consistent estimate for the effect of $m l$ on $y$ when $x$ is used as an instrument. But, suppose the modeler examined the effect of $m 2$ on $y$, as suggested in Figure 4, and that (a) $m 2$ and $m 1$ correlate, (b) $x$ is a cause of $m 2$, but (b) $m 2$ is not a true cause of $y$. Whether or not $x$ is manipulated or a measured instrumental variable, the following instrumental-variable model will provide a significant but incorrect estimate for the effect of $m 2$ on $y: x \rightarrow m 2 \rightarrow y$, what we call "specious mediation." If however, the modeler knows of another true cause of $m 2$ (i.e., suppose $z$ is a true cause of $m 2$ that is largely orthogonal to $x$ ), the following instrumental variable model will show that $m 2$ does not cause $y$ : $z \rightarrow m 2 \rightarrow y$. An instrumental-variable model including both $m 1$ and $m 2$ as predictors of $y$, instrumented by $x$ and $z$, will provide the same estimates as the two piecewise models $x \rightarrow m 1 \rightarrow y$ and $z \rightarrow m 2 \rightarrow y$. Yet different instruments and mediators are usually correlated. We thus suggest that researchers theorize, investigate and test the most likely mediation paths in one rather than in several piecewise models.

${ }^{2}$ These instruments or predictors of the mediator, here called the "excluded instruments," must only be included in the equation predicting the mediator (i.e., the $m$ equation) and must be 
excluded from the equations predicting the dependent variable/s (i.e., the $y$ equation); only extra exogenous predictors, beyond the excluded instruments, can be included both in the mediator and in the $y$ equation (Antonakis et al., 2010; Wooldridge, 2002), to test "partial mediation effects." Also, the instruments must be strongly related to the mediators; and, if the endogenous mediator, $m$, is a true cause of $y$, then the instrument must also correlate with $y$ (Bollen, 2012). Fulfilling these conditions is a necessary for parameter identification (Wooldridge, 2002). Such models, whether with or without latent variables, can be estimated via two-stage least squares or maximum likelihood (Antonakis et al., 2010; Bollen, 1996; Shaver, 2005).

${ }^{3}$ Empowering leadership, as is any leadership style or behavior, is an endogenous construct. It certainly can be manipulated in a laboratory or in a field experiment. However, when studying its natural variation in the field, it is important control for omitted variables or to "instrument" empowerment because this type of leader behavior could (a) be driven by organizational level factors, selection factors, and leader traits, which may also correlate with the outcomes too, or (b) be simultaneously caused by the outcome (e.g., if team members are more conscientious, better workers, and are able to handle more responsibility, then the leader “empowers" them). 
Table 1

Taxonomy of Leadership Mediation Constructs

Type of leadership process

\begin{tabular}{|c|c|c|}
\hline $\begin{array}{l}\text { Level of } \\
\text { analysis }\end{array}$ & Developing & Leveraging \\
\hline Individual & $\begin{array}{l}\text { Developing individual resources } \\
\text { - } \quad \text { Developmental experiences } \\
\text { (Zaccaro et al., 2015) } \\
\text { - } \quad \text { Developmental peer appraisal } \\
\text { (Druskat \& Wolff, 1999) } \\
\text { - Empathy (Kellett, Humphrey \& } \\
\text { Sleeth, 2006) } \\
\text { - Belief structure (Beyer, } \\
\text { Chattopadhyay, George, Glick \& } \\
\text { Pugliese, 1997) }\end{array}$ & 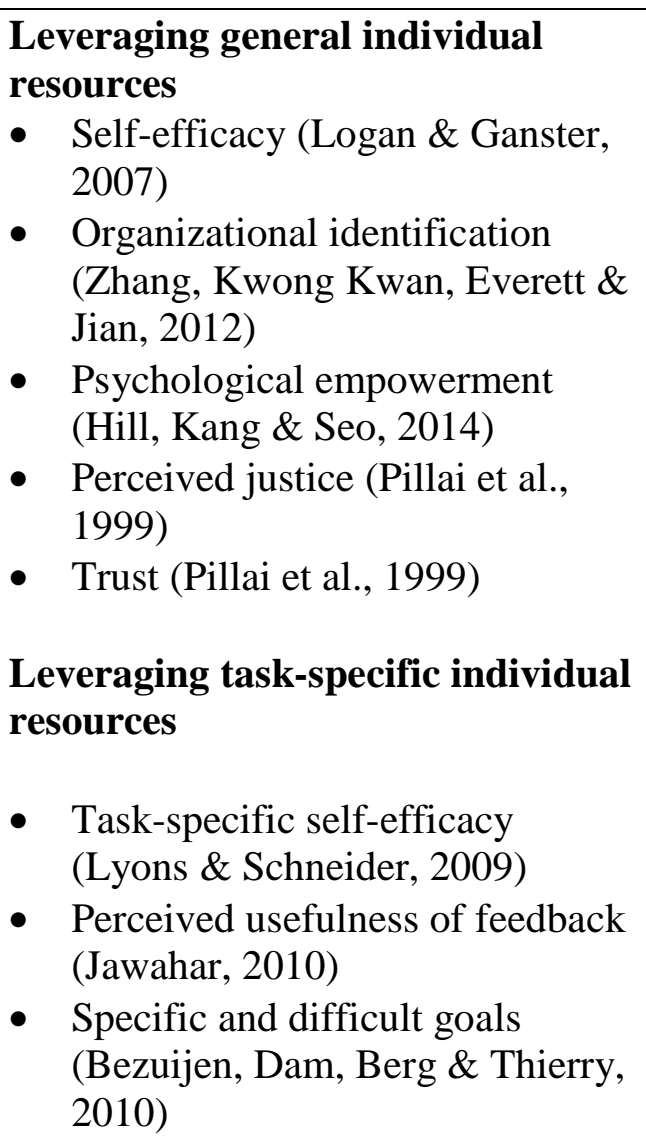 \\
\hline Team & $\begin{array}{l}\text { Developing team resources } \\
\text { - } \quad \text { Team mental model } \\
\text { similarity (Ayoko \& Chua, } \\
\text { 2014) } \\
\text { - } \quad \text { Team learning (Edmondson, } \\
\text { 2003) } \\
\text { - Team-level career mentoring } \\
\text { (Williams, Scandura \& } \\
\text { Gavin, 2009) } \\
\text { - Team coaching (Hackman \& } \\
\text { Wageman, 2005)* }\end{array}$ & $\begin{array}{l}\text { Leveraging general team resources } \\
\text { - Collective team identification } \\
\text { (Kearney, Gebert \& Voelpel, } \\
\text { 2009) } \\
\text { - Team service climate (Hunter, } \\
\text { Neubert, Perry, Witt, Penney \& } \\
\text { Weinberger, 2013) } \\
\text { - Team empowerment (Kirkman, } \\
\text { Tesluk \& Rosen, 2004) } \\
\text { - Group solidarity (Houghton, } \\
\text { Pearce, Manz, Courtright \& } \\
\text { Stewart, 2015) }\end{array}$ \\
\hline
\end{tabular}




\begin{tabular}{|c|c|c|}
\hline & & $\begin{array}{l}\text { Leveraging team-specific resources } \\
\text { - Elaboration of task-related } \\
\text { information (Kearney et al., } \\
\text { 2009) } \\
\text { - Team priority of safety (Leroy et } \\
\text { al., 2012) } \\
\text { Task conflict (Olson, Parayitam } \\
\text { \& Bao, 2007) } \\
\text { - Challenging unit goals (Crossley, } \\
\text { Cooper \& Wernsing, 2013) }\end{array}$ \\
\hline $\begin{array}{l}\text { Organi- } \\
\text { zational }\end{array}$ & 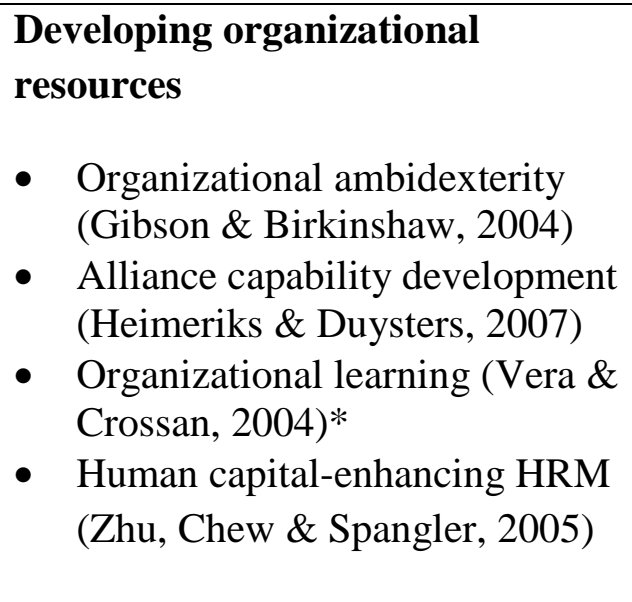 & $\begin{array}{l}\text { Leveraging organizational } \\
\text { resources } \\
\text { - Collective organizational } \\
\text { engagement (Barrick, Thurgood, } \\
\text { Smith \& Courtright, 2015) } \\
\text { - Family-friendly work practices } \\
\text { (Ngo, Foley \& Loi, 2009) } \\
\text { - Organizational climate (Ngo et } \\
\text { al., 2009) } \\
\text { TMT internal ties (Collins \& } \\
\text { Clark, 2003) }\end{array}$ \\
\hline External & $\begin{array}{l}\text { Developing external resources } \\
\text { - Boundary loosening / tightening } \\
\text { activities (Somech \& Khalaili, } \\
\text { 2014) } \\
\text { - Network centrality (Ho \& } \\
\text { Pollack, 2014) } \\
\text { - External ties (Balkundi \& } \\
\text { Kilduff, 2006)* } \\
\text { - Interorganizational trust (Uzzi, } \\
\text { 1997)* }\end{array}$ & \\
\hline
\end{tabular}

Note: Articles with a “*” were not mediation models from the sample of 657 articles; we have chosen to portray them here so as to provide readers with information for a more integrative understanding of leadership. 
Table 2

List of Coding Event

\begin{tabular}{lcccc}
\hline & $\begin{array}{c}\text { Modeling multiple } \\
\text { mediation paths }\end{array}$ & $\begin{array}{c}\text { Avoiding same source } \\
\text { sampling }\end{array}$ & $\begin{array}{c}\text { Use of exogenous } \\
\text { predictor }\end{array}$ & $\begin{array}{c}\text { Use of instrumental } \\
\text { variable approach }\end{array}$ \\
\hline Yes & 69 & 40 & $49^{\mathrm{a}}$ & 3 \\
& & & & \\
No & 120 & 149 & 140 & 186 \\
\\
$\begin{array}{l}\text { Percentage } \\
\text { of yes }\end{array}$ & $37 \%$ & $21 \%$ & $26 \%$ & $2 \%$ \\
\hline
\end{tabular}

Total number of quantitative-empirical articles: 189

a 22 articles use an exogenous experimental manipulation, and 28 articles use stable predictors like IQ.

${ }^{\mathrm{b}} 43$ articles use standard measurement of time lags ( $\mathrm{t} 1, \mathrm{t} 2$, etc.) in field studies and 22 articles use sequential measurement in laboratory experiments.

We report on the use of time lags in the section about time.

Note that all percentages are rounded to zero-decimal numbers. 
Figure 1

General Model of Multi-Level Leadership Performance

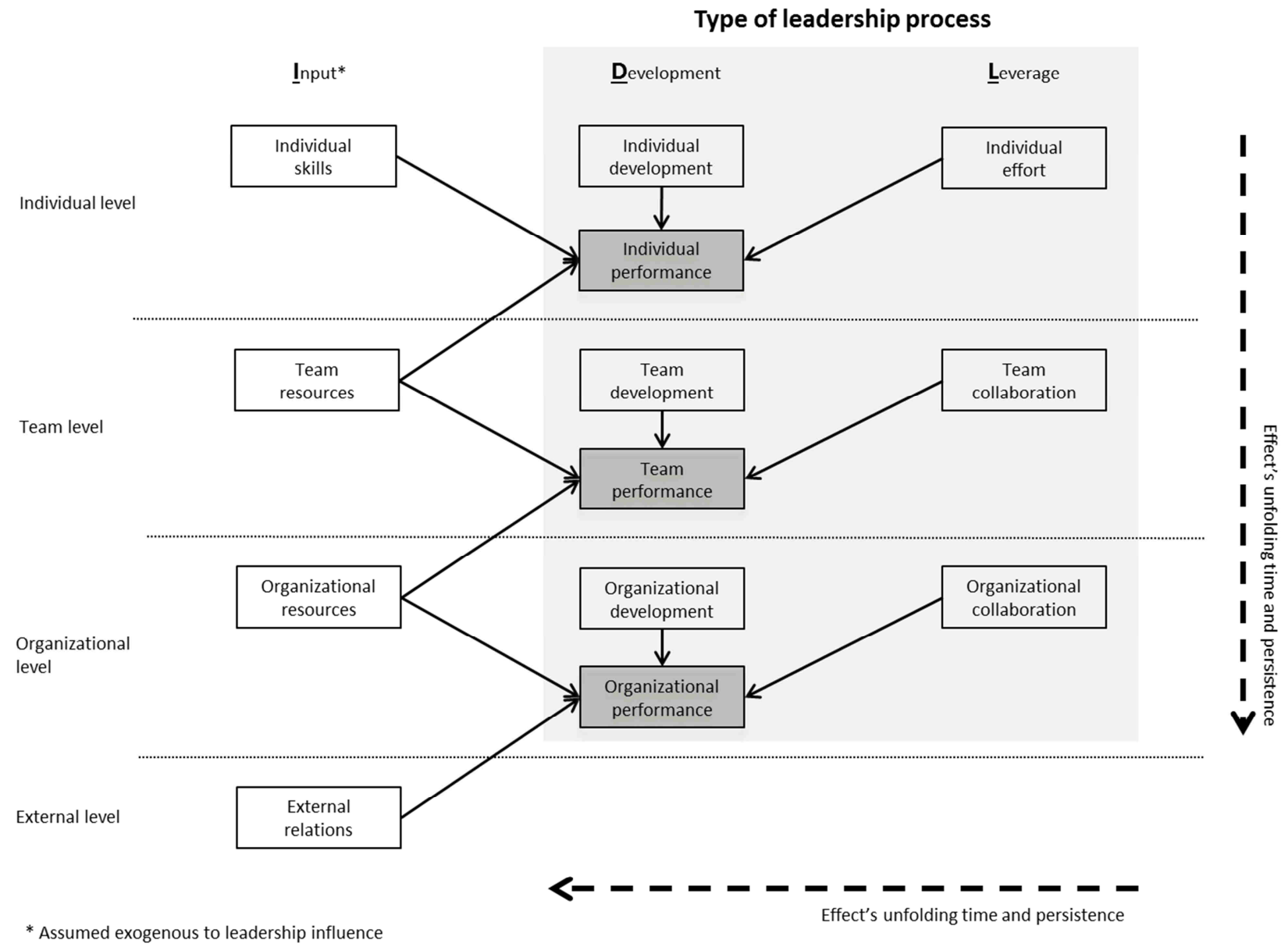

Note: In our review, we focus on the gray area. Furthermore, we discuss the dashed arrows in the section about time. 
Figure 2

Predominantly Studied Leader-Target-Outcome Relationships

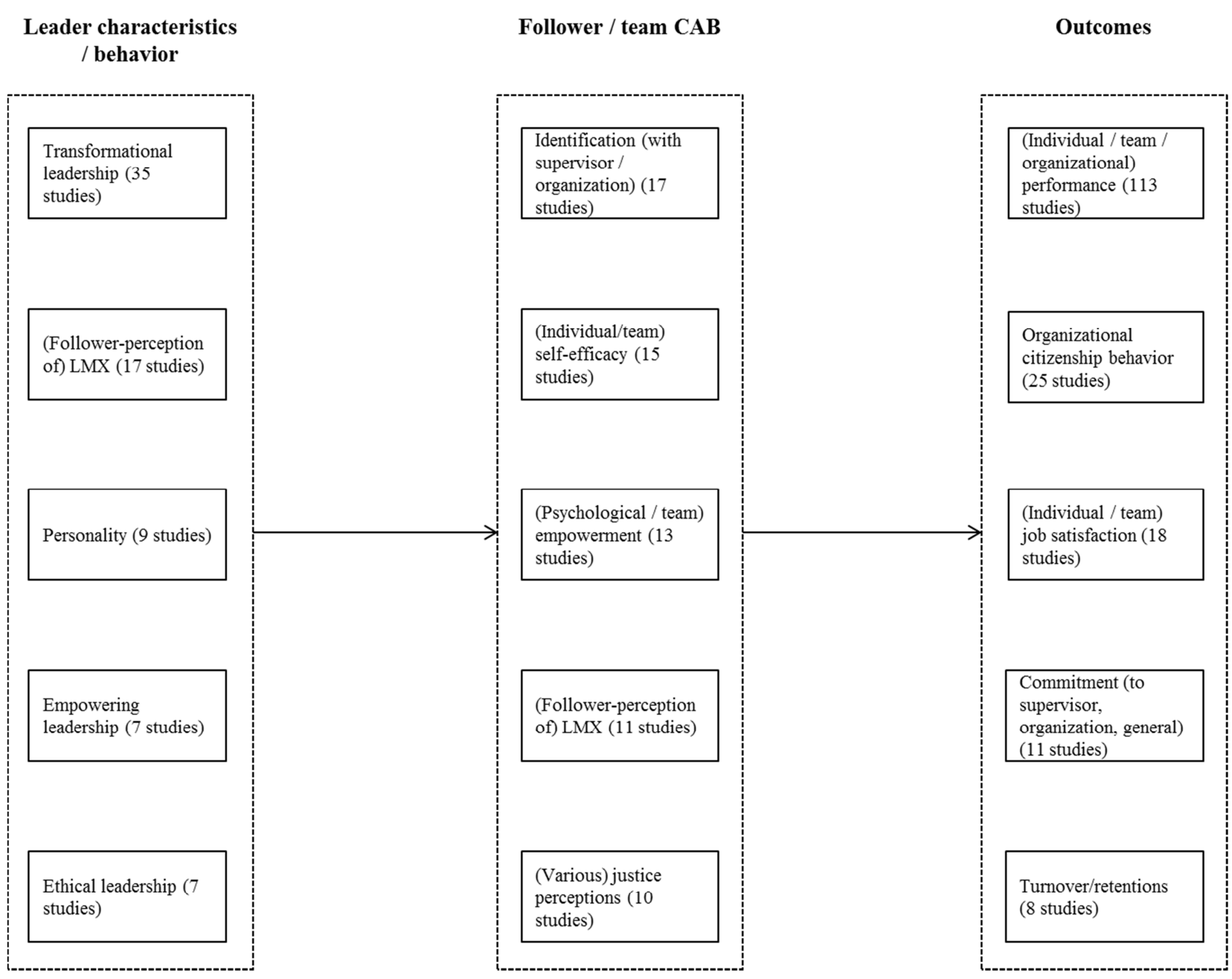

Note: $\mathrm{CAB}=$ Cognitions, affect, and behaviors 


\section{Figure 3}

Typical and Overlooked Mediation Models

\section{Understudied domains}

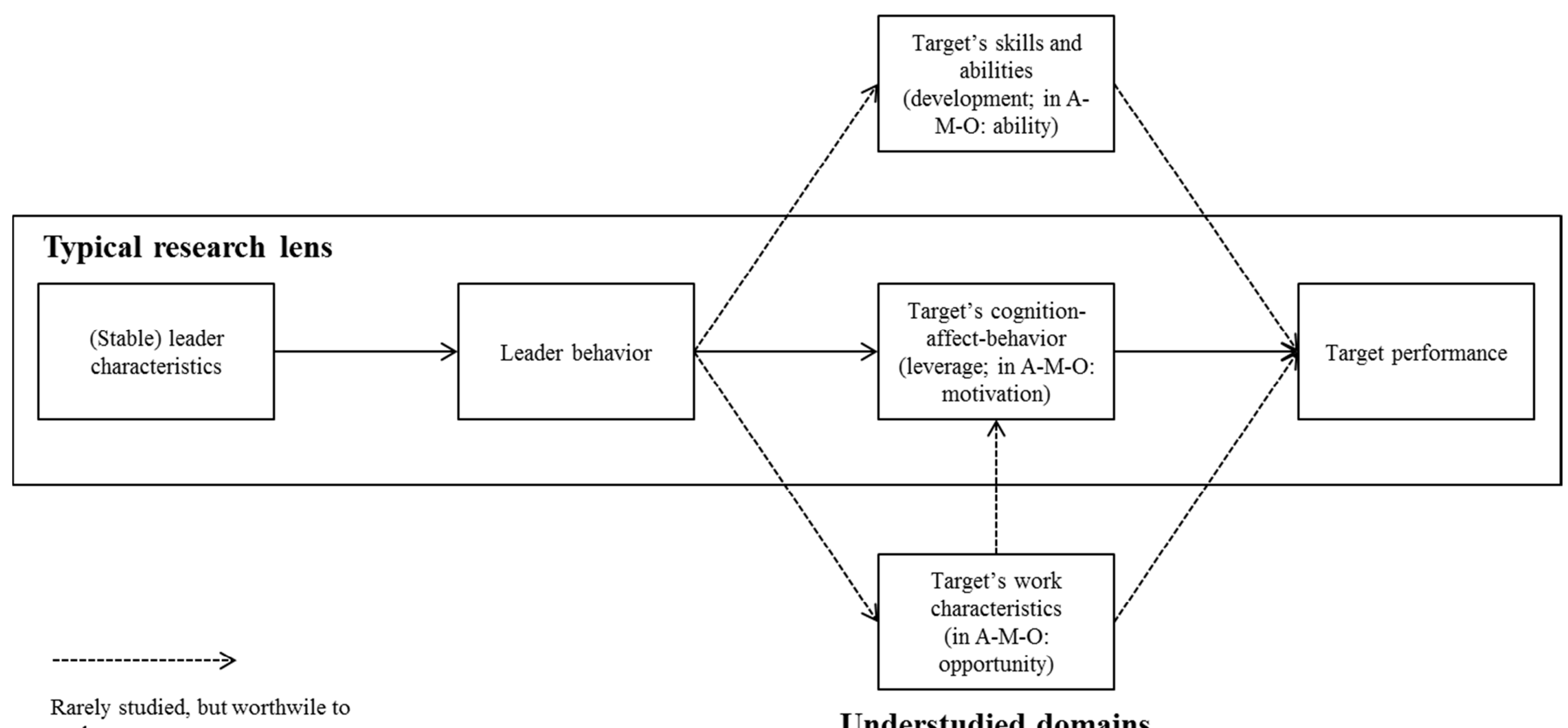

Rarely studied, but worthwile to analyze more

\section{Understudied domains}

Note: Depending on the level of analysis, the target is either the individual follower, the team, the organization as a whole, or the extraorganizational environment. 
Figure 4

The Specious Mediator Problem

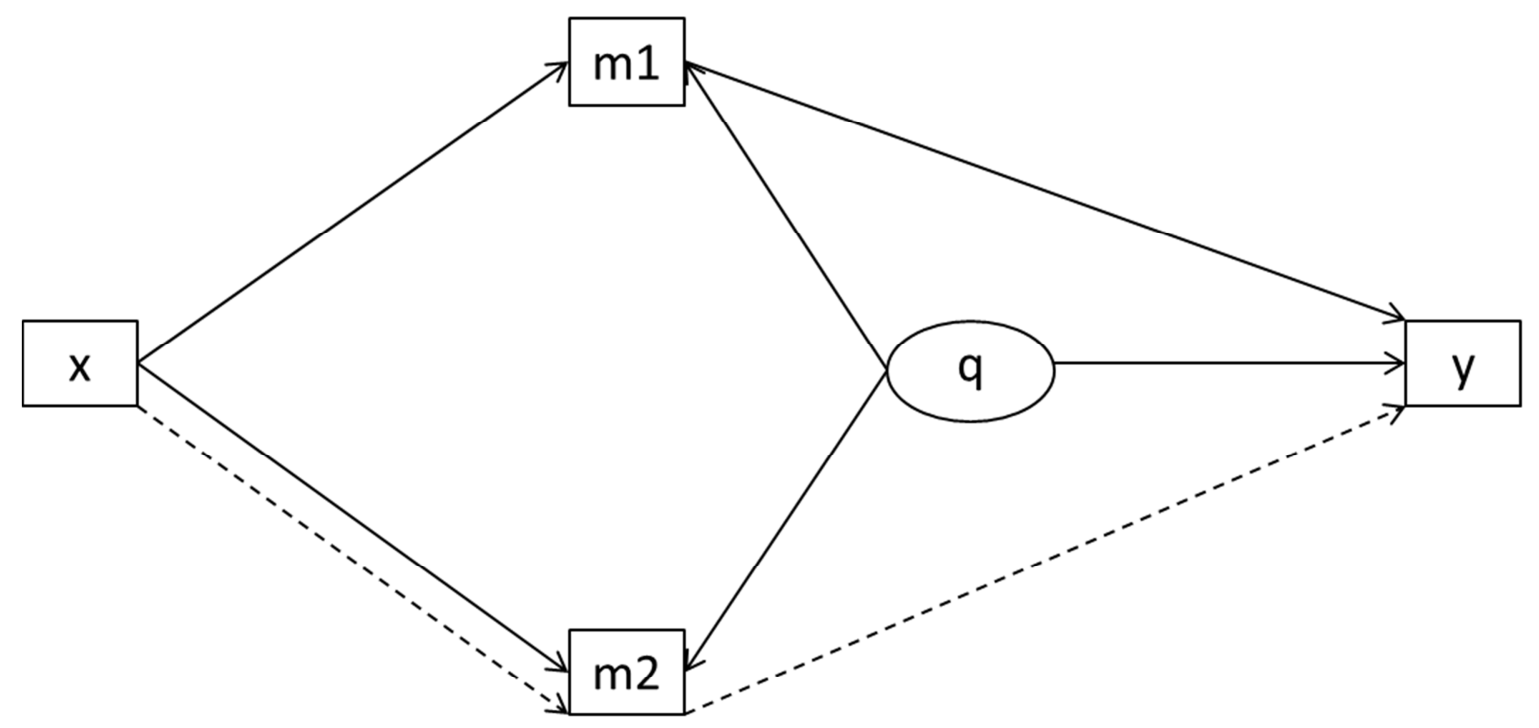

True causal mechanism

Estimated causal mechanism

Note: Including the true mediator in the empirical model avoids finding a specious mediator and is thus a necessary but still not sufficient condition for obtaining proper parameter estimates. In order to test the model with the two endogenous mediators $m 1$ and $m 2$ (and with $q$ an unknown and omitted cause), one needs also a second exogenous predictor that is related to either $\mathrm{m} 1$ or $\mathrm{m} 2$, or both, and to estimate the model using an instrumental variable estimator. Otherwise, the empirical model will be causally unidentified (Antonakis et al., 2010). 


\section{ONLINE APPENDIX 1}

Number of articles studying leader mediation models over time

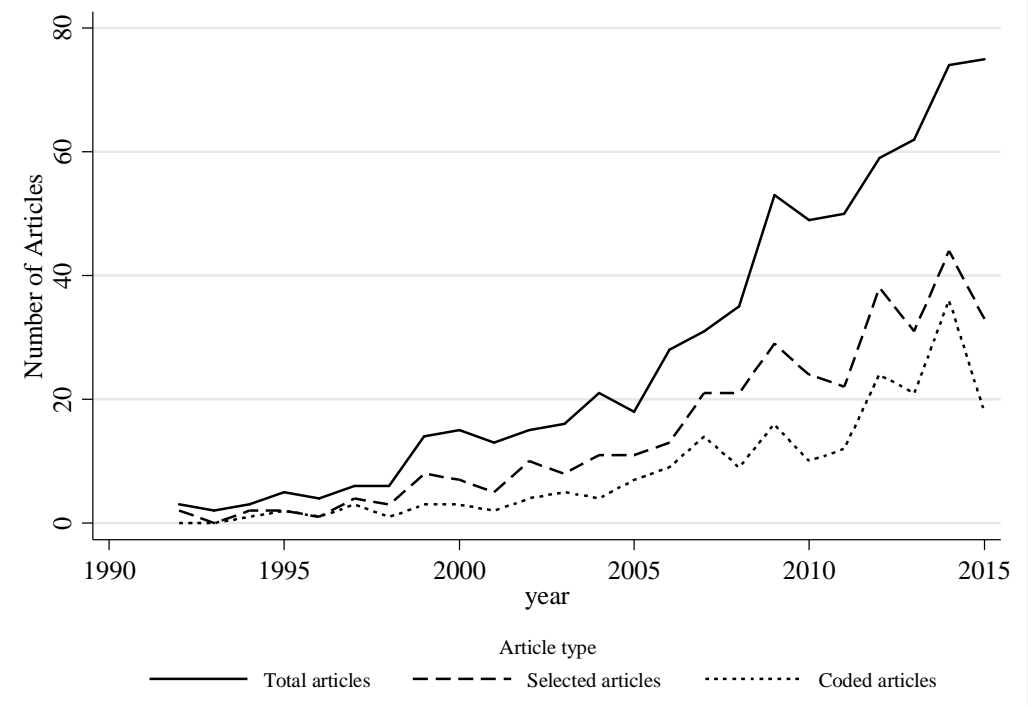




\section{ONLINE APPENDIX 2}

\section{List of journals included in our sample}

The journals included in our search, and listed here in order of five-year impact factor, are the following (the numbers in parentheses refer to number of articles we found in the journal, first referring to the total sample and the second to the randomly picked sample): Academy of Management Journal $(61 ; 31)$, Journal of Management $(44 ; 18)$, Journal of Applied Psychology (128; 69), Administrative Science Quarterly (5; 2), Organization Science (15;11), Personnel Psychology (22; 12), Journal of International Business Studies $(9 ; 4)$, Strategic Management Journal (14; 5), Journal of Management Studies (20;12), International Journal of Management Reviews (1; 1), Academy of Management Perspectives (0; 0), Journal of Organizational Behavior (68; 32), The Leadership Quarterly (112; 61), Organizational Behavior and Human Decision Processes $(31 ; 17)$, Organization Studies $(7 ; 4)$, Human Resource Management Review (5; 4), Journal of Occupational and Organizational Psychology $(20 ; 12)$, Research in Organizational Behavior $(1 ; 1)$, Management Science $(2 ; 2)$, Human Relations (16; 6), Academy of Management Learning \& Education (2; 2), Management and Organization Review (8; 3), Group \& Organization Management (38; 25), Human Resource Management Journal (4; 3), Human Resource Management (24; 13). 
ONLINE APPENDIX 3

Predictors of Leadership

\begin{tabular}{|c|c|c|}
\hline \multicolumn{2}{|c|}{ Type of predictor } & \multirow{2}{*}{$\begin{array}{l}\text { Number of studies using } \\
\text { such a predictor-type }\end{array}$} \\
\hline & Characteristics & \\
\hline 这 & Behavior & 106 \\
\hline - & Other (e.g., cognition) & 17 \\
\hline 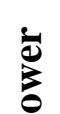 & $\begin{array}{l}\text { Characteristics, cognition, affect, and } \\
\text { behavior }\end{array}$ & 49 \\
\hline ڤ్ & Relationship & 24 \\
\hline 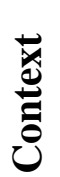 & Contextual factors & 32 \\
\hline
\end{tabular}

Note: The predictors of the 189 quantitative-empirical studies were assigned to one of the six categories. In total, there are 267 coding events; thus some studies used multiple types of predictors (e.g., leader behavior and contextual factors). Overall, 156 (more than 82\%) studies used at least one leader-level predictor. 
ONLINE APPENDIX 4

Frequencies of Coding Events for the Target-Centric Mediator Taxonomy

\begin{tabular}{lll}
\hline & Development & Leverage \\
\hline Individual & $15(4 \%)$ & General \\
& $190(55 \%)$ \\
& i) Cognitive: $87(25 \%)$ \\
& ii) Affective: $44(13 \%)$ \\
& iii) Behavioral: $34(10 \%)$ \\
& iv) Cognitive-affective: $19(5 \%)$ \\
& v) Other: $6(2 \%)$
\end{tabular}

\section{Task-specific}

$9(3 \%)$



Team

$10(3 \%)$

General

$66(19 \%)$

i) Cognitive: 28 (8\%)

ii) Affective: $10(3 \%)$

iii) Behavioral: $20(6 \%)$

iv) Cognitive-affective: $6(2 \%)$

v) Other: $2(1 \%)$

\section{Task specific}

$15(4 \%)$

Organizational 0

\section{General}

$8(2 \%)$

\section{Task specific}

0

External

$7(2 \%)$

Note: In total, in the 205 studies, 347 mediators were coded (some studies had multiple mediators). Out of these, $92 \%$ could be assigned to one of the target-centric categories. Also note that all percentages are rounded to zero-decimal numbers. 
ONLINE APPENDIX 5

Trends in coded articles over time for certain criteria

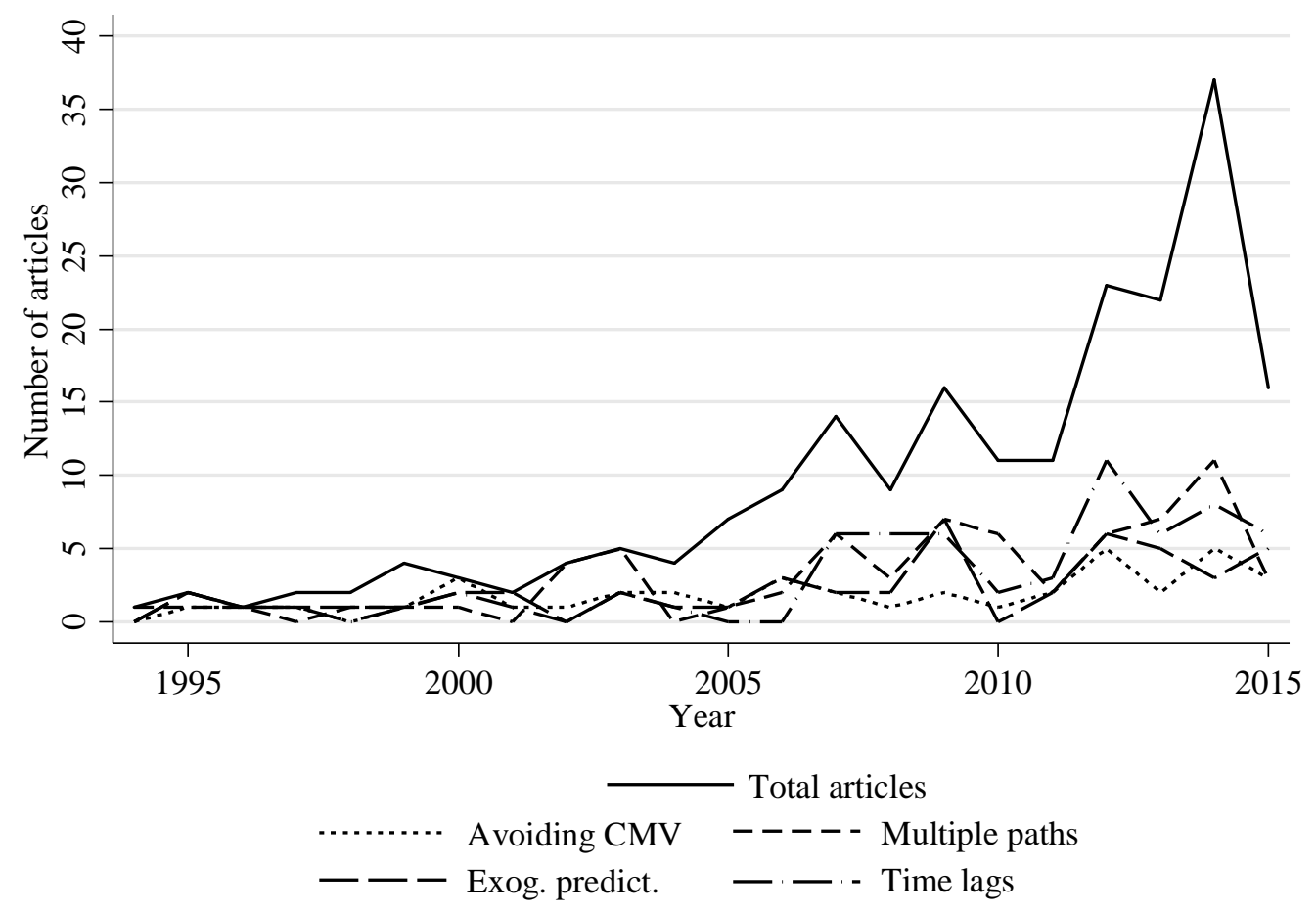

Note: In the above figure we show the raw numbers of article and coded trends. However, to better understand the trends over time, note that as a percentage of total articles, these trends are negative over time. That is, with time, the research designs are getting weaker and significantly so for all except time-lags (at $p \leq .05$ ). 